Article

\title{
Geographic Patterns of Fire Severity Following an Extreme Eucalyptus Forest Fire in Southern Australia: 2013 Forcett-Dunalley Fire
}

\author{
Mercy N. Ndalila *(1), Grant J. Williamson $(1)$ and David M. J. S. Bowman \\ School of Natural Sciences, University of Tasmania, Private Bag 55, Hobart, TAS 7001, Australia; \\ grant.williamson@utas.edu.au (G.J.W.); david.bowman@utas.edu.au (D.M.J.S.B.) \\ * Correspondence: mercy.ndalila@utas.edu.au; Tel.: +61-469-833-635
}

Received: 19 July 2018; Accepted: 20 October 2018; Published: 22 October 2018

\begin{abstract}
Fire severity is an important characteristic of fire regimes; however, global assessments of fire regimes typically focus more on fire frequency and burnt area. Our objective in this case study is to use multiple lines of evidence to understand fire severity and intensity patterns and their environmental correlates in the extreme 2013 Forcett-Dunalley fire in southeast Tasmania, Australia. We use maximum likelihood classification of aerial photography, and fire behavior equations, to report on fire severity and intensity patterns, and compare the performance of multiple thresholds of the normalised burn ratio (dNBR) and normalized difference vegetation index (dNDVI) (from pre- and post-fire Landsat 7 images) against classified aerial photography. We investigate how vegetation, topography, and fire weather, and therefore intensity, influenced fire severity patterns. According to the aerial photographic classification, the fire burnt 25,950 ha of which $5 \%$ burnt at low severities, $17 \%$ at medium severity, $32 \%$ at high severity, $23 \%$ at very high severities, while $22 \%$ contained unburnt patches. Generalized linear modelling revealed that fire severity was strongly influenced by slope angle, aspect, and interactions between vegetation type and fire weather (FFDI) ranging from moderate (12) to catastrophic ( $>100)$. Extreme fire weather, which occurred in $2 \%$ of the total fire duration of the fire (16 days), caused the fire to burn nearly half $(46 \%)$ of the total area of the fireground and resulted in modelled extreme fireline intensities among all vegetation types, including an inferred peak of $68,000 \mathrm{~kW} \cdot \mathrm{m}^{-1}$ in dry forest. The best satellite-based severity map was the site-specific dNBR ( $45 \%$ congruence with aerial photography) showing dNBR potential in Eucalyptus forests, but the reliability of this approach must be assessed using aerial photography, and/or ground assessment.
\end{abstract}

Keywords: aerial photography; Eucalyptus forest; fire severity mapping; normalized burn ratio; fire intensity; geospatial validation; generalized linear modelling; Tasmania

\section{Introduction}

Fire regimes are a multidimensional concept that capture the spatiotemporal variation in landscape fire in terms of physio-chemical processes and biological effects [1,2]. A key facet of the fire regime concept is fire severity, which is defined as the degree of post-fire ecological change associated with loss of organic matter aboveground and belowground [3,4]. Fire severity is important to quantify and map because it affects smoke and greenhouse gas emissions [5], plant and animal demographic processes [6,7], correlates with property damage [8], and influences habitat quality and geomorphological processes [9]. Fire severity is different from fire intensity, which refers to the energy output of a fire during burning, although both concepts are loosely connected $[4,10]$. For instance, a fast, high-intensity flaming fire in grassland ecosystems can produce less severe impacts than 
slow-combusting smoldering fires in heavy fuels $[3,11]$. The most commonly used fire intensity metric is fireline intensity, defined as the rate of energy release per unit length of firefront [12]. Fire intensity during a wildfire event is difficult to measure because of the associated risks relating to operating under a dangerous environment, and fire management agencies prioritize fire suppression and saving lives above research and data acquisition [13]. Consequently, fire behavior modelling provides a practical alternative means of estimating fire intensity.

Fire severity is also challenging to assess because it is a three-dimensional concept, capturing fire impacts on vegetation in the horizontal and vertical planes. Fire severity assessments involve field-based measurements, remote sensing (RS) analysis, or simulation modelling (e.g., Keane et al. [14], Loschiavo et al. [15]), although a combination of field and RS is more common. Field methods assess actual fire effects on vegetation, such as plant mortality, canopy scorching and defoliation, diameter of burnt twigs, fuel load consumption, changes in soil characteristics, and ash deposition [3]. An example is the composite burn index (CBI) [16], which aggregates severity ratings at different vegetation strata within a $30 \mathrm{~m}$ diameter plot into an overall rating, ranging from zero (unburned) to three (high severity). Remote sensing methods enable fire severity assessments at broader temporal and spatial scales. Change detection (using spectral indices) and supervised image classification are the most common mapping methods. The normalized burn ratio (NBR) [16] and normalized difference vegetation index (NDVI) [17] are the most commonly applied indices.

NBR has been extensively used in western U.S. coniferous forests [18-23], but less so in tropical savannas [24-26], Mediterranean ecosystems [27-30], and boreal forests [5,31,32]. Very few published studies have applied NBR in mapping fire severity patterns in wildfires in temperate Eucalyptus-dominated forests of Australia [33-36], largely because of: (1) the general unavailability of usable satellite images that are cloud-free, (2) availability of other imagery that typically lack a shortwave infrared (SWIR) band required for NBR computation [33], and (3) availability of higher resolution imagery that are more attractive for fire severity assessments. In Australia, this situation is exacerbated by a lack of a nationally-adopted method of measuring and mapping fire severity. Consequently, fire severity assessments using NDVI (which does not require the SWIR band) from non-Landsat imagery (e.g., Satellite Pour l'Observation de la Terre (SPOT 6) and aerial photography, both of which provide a higher spatial resolution), have been the most preferred in Eucalyptus forests (e.g., $[10,15,37,38])$.

Field data are typically used to train and validate remotely sensed fire severity mapping products because remote sensing data are usually captured in a two-dimensional top-down perspective, while fire severity is a three-dimensional biological concept. Validation of fire severity mapping (with NBR) in the United States and other regions has extensively used the field assessment of CBI. Where ground observations are lacking or inadequate, indirect validation through inter-comparison with other remotely-sensed products or upscaling (integration of field measurements and a high-resolution, remotely-sensed imagery) can be made [39,40]. For instance, in the Australian context, aerial photography is the common data source for accuracy assessment of satellite observations (e.g., [38,41,42]) or for stratifying field assessments of wildfire severity (e.g., [10,35,37]).

In temperate Eucalyptus forests, fire severity assessments are increasingly being used by fire ecologists to understand the impacts of intense fires, and the legacy effects of land use such as logging and prescribed burning $[6,43,44]$. However, the satellite-based approach remains nascent in these ecosystems and particularly in Tasmania. In this context, the Forcett-Dunalley fire event in south-eastern Tasmania presents an excellent opportunity to study fire severity patterns using remote sensing techniques applied to both aerial photography and satellite imagery informed by a post-fire field survey.

Here, we use multiple lines of evidence to understand fire severity and intensity patterns and their environmental correlates in the extreme 2013 Forcett-Dunalley fire in southeast Tasmania, Australia. We specifically: (1) describe the geographical patterns of fire severity using a classification of multispectral aerial photography across the Forcett-Dunalley fireground, informed by field truthing 
after the fire; (2) model the variation in fire intensity and flame heights among different vegetation types and associate these differences to fire weather and fuel loads; (3) evaluate congruence between the generated aerial photography fire severity map and four approaches of satellite analyses of fire severity; (4) quantify the temporal variation of fire severity across the course of the fire in different vegetation types; and (5) determine environmental factors that influenced the observed fire severity patterns as well as congruence between aerial and satellite-based mapping.

\section{Materials and Methods}

\subsection{Study Area}

Tasmania is the island state of Australia, located between $41^{\circ}-44^{\circ} \mathrm{S}$ and $145^{\circ}-149^{\circ} \mathrm{E}$, covering an area of approximately 6.8 Mha. The island has mountains and a high plateau of $1600 \mathrm{~m}$, a dry low elevation interior rift valley, and coastal plains (Figure 1a). The climate is temperate, with a pronounced summer-winter contrast in day length and temperature, which is also strongly affected by elevation, resulting in treeless alpine vegetation at around $1000 \mathrm{~m}$ above sea level. There is a marked west to east orographic rainfall gradient associated with the interaction with westerly winds [45].

The locus of this study is the Forcett-Dunalley fireground located in the southeast of the island on, and adjoining, the Forestier and Tasman Peninsulas. This fire was one of five fires that burnt over 87,000 ha (Figure 1a) during an extreme fire weather event, associated with antecedent drought and strong north-westerly winds, driven by the interaction of a high-pressure system and a cold front that brought hot air over Tasmania on 3-4 January [46]. The Forcett-Dunalley fire started at 2 pm on 3 January 2013, possibly from a stump that had been burning since late December 2012 in a property in the town of Forcett, northwest of the fireground [47]. From 3-4 January, a highly unstable middle-level atmosphere, high temperatures (reaching $41.8^{\circ} \mathrm{C}$ ), strong north-westerly winds (gusting to $70-90 \mathrm{~km} \cdot \mathrm{h}^{-1}$ ), low relative humidity, and dry fuels (predominately in long unburned Eucalyptus forest) interacted to form the worst daily fire weather in Tasmania since the disastrous 1967 fire season [46]. Under these extreme weather conditions, the fire destroyed 250 residential and commercial properties, concentrated in the township of Dunalley (Figure 1c), an event that attracted global media attention [48] and led to formation of the 2013 Tasmanian Bushfires Inquiry [46]. The fire then burned for another 14 days under much more moderate fire weather conditions, creating strong contrasts in fire severity across the fireground. Marsden-Smedley [47] reported that the fire burnt approximately 24,000 ha of native forests, agricultural properties, and forest plantations (Figure 1b).

The fireground has a cool moist maritime climate, with mean annual rainfall ranging from $600 \mathrm{~mm}$ in the north-west to $1000 \mathrm{~mm}$ in the southeast (Figure 1c), and mean daily temperatures of $17^{\circ} \mathrm{C}$ in summer and $9{ }^{\circ} \mathrm{C}$ in winter. The geology of the region is an intermix of igneous and sedimentary rocks that form a low (ca. maximum $600 \mathrm{~m}$ above sea level) topography complex. The drowning of valleys and coastal plains following deglaciation formed numerous narrow peninsulas with undulating terrain, surrounded by numerous bays and low headlands (Figure 1c). The main vegetation types include wet Eucalyptus forests and patches of temperate rainforest on sheltered southerly slopes and gullies in higher rainfall areas in the south-east; and dry sclerophyll forests on infertile soils and north-facing slopes in drier areas (Figure 1 b). About $20 \%$ of the area has been cleared for agriculture and low-density settlement. 


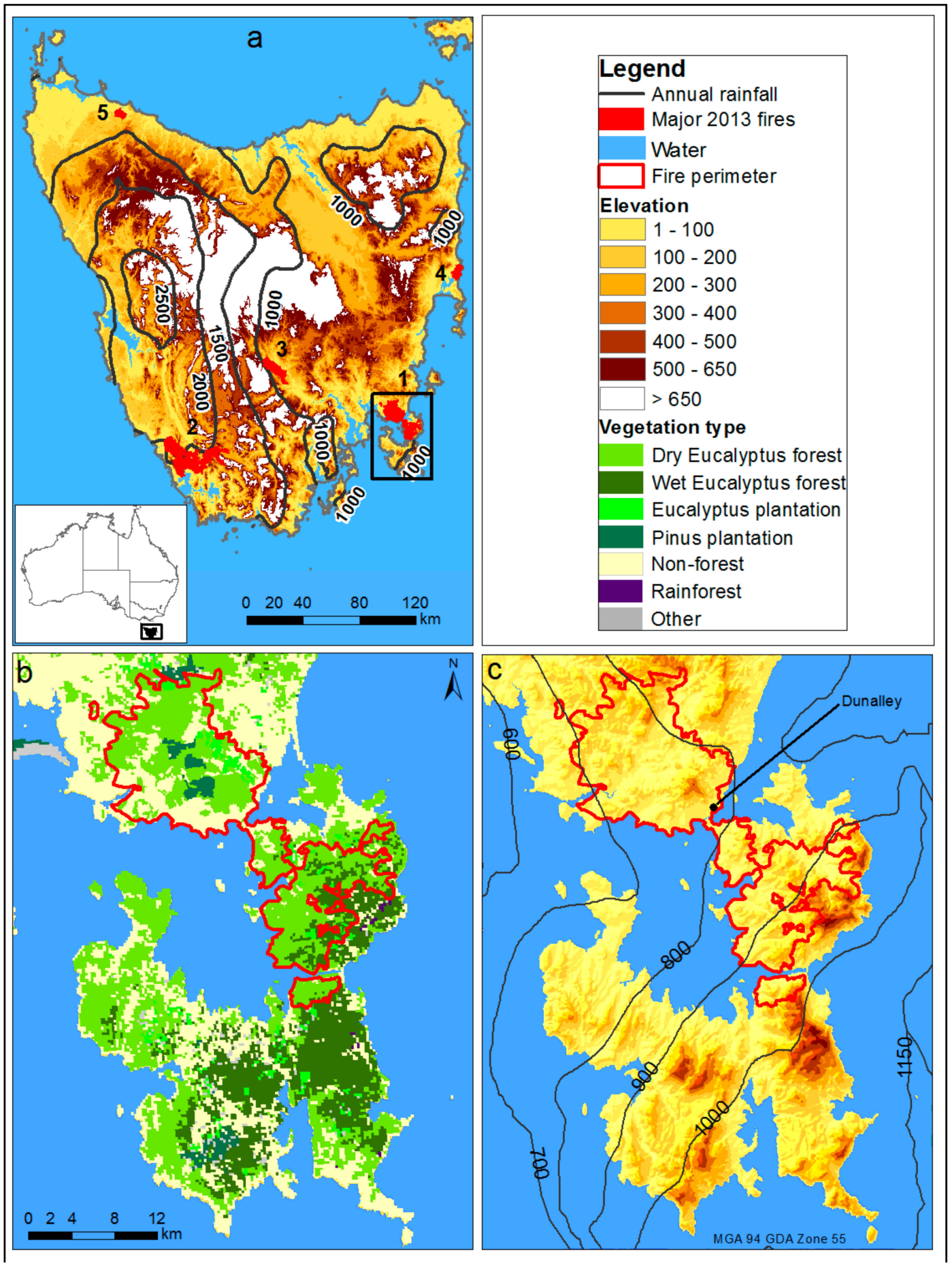

Figure 1. Geographic context of the Forcett-Dunalley fireground: (a) Annual rainfall (in millimetres) and elevation (in metres) across Tasmania and the location of major fires in the 2013 fire season: 1-Forcett-Dunalley; 2-Giblin River; 3-Repulse; 4-Bicheno; 5-Montumana. (b) Dominant vegetation in the Forestier and Tasman Peninsulas based on TASVEG 3.0, an integrated vegetation map of Tasmania [49]. (c) Elevation displayed as hillshaded Digital Elevation Model, and mean annual rainfall across the Forestier and Tasman Peninsulas. 


\subsection{Data Harmonisation and Analysis}

We employed two distinct image types as primary datasets: $25 \mathrm{~cm}$ resolution orthorectified aerial photography and pre- and post-fire $30 \mathrm{~m}$ resolution Landsat 7 satellite images. The aerial photography was provided by the Tasmanian Fire Service, and obtained from an aircraft flown in the NE-SW direction at a height of approximately 2700 feet around 20 January 2013, immediately after the fire. The data were collected as mosaics in the red, green, blue, and near infrared (NIR) bands. We acknowledge that using an image collected shortly after a fire may mask the full effects of crown scorch and consumption and there is a chance that fire severity may be underestimated, although complete and intermittent crown fires were readily apparent in the aerial photography (see Figure S1). Further, we undertook additional fire severity assessments by conducting a field survey in forests in 2018. Landsat 7 scenes for path 89/row 90 acquired by the ETM+ sensor were downloaded from the United States Geological Survey website (https:/ / earthexplorer.usgs.gov/) for pre-fire (27 January 2012) and post-fire (29 January 2013) dates. These images were obtained as Level-2 products (https:/ / landsat.usgs.gov/landsat-surface-reflectance-data-products), having been orthorectified and with data already converted into surface reflectance. Due to the scan line corrector failure affecting this period [50], additional separate Level-2 images collected within a month of the acquisition times of the primary Landsat images were used to fill missing data gaps (pre-fire images: 3 February 2012 (path 90/row 90), and 12 February (path 89/row 90); post-fire images: 5 February 2013 (path 90/row 90), and 14 February 2013 (path 89/row 90).

To allow for the combination of geographic data with different spatial resolutions, we used a $50 \times 50 \mathrm{~m}$ grid as our unit of analysis, which was considered appropriate for the purposes of landscape ecology analysis. The extent and type of vegetation was obtained from the vegetation layer TASVEG 3.0 [49], each grid cell was attributed with the vegetation type with the largest area within that cell. TASVEG contains a description of 162 mapping units of natural vegetation found in Tasmania, grouped into dry Eucalyptus forest and woodland, wet Eucalyptus vegetation, native grasslands, modified land, non-eucalypt vegetation, among other plant groups. Fire history, fire perimeter, and fire progression isochrones were obtained from the unpublished records held by the Tasmanian Fire Service. Using a $33 \mathrm{~m}$ digital elevation model (DEM) provided by the Tasmanian Department of Primary Industries, Parks, Water and Environment (DPIPWE), we applied the terrain function in the R package raster [51] to calculate slope, aspect, and topographic position index (TPI). TPI is an index that classifies a cell according to its position within the landscape by measuring the difference between the altitude of that cell and the mean altitude of its neighbors [52]. Positive values represent hilltops and ridges, negative values indicate valleys and gullies, while values close to zero indicate flat areas or mid-slopes. Grid cells were attributed with the mean slope, most frequent aspect, and mean topographic position index.

Hourly gridded weather data was obtained from a downscaled initial analysis product provided by the Antarctic Climate and Ecosystems Cooperative Research Centre, Hobart, Tasmania at $1.5 \mathrm{~km}$ spatial resolution [53]. These data included air temperature, relative humidity, wind speed, and McArthur forest fire danger index (FFDI) [54]. Weather data were assigned to cells based on the spatial overlap with fire progression isochrones to enable estimation of meteorological variables for each cell at the time of combustion. Grid cells were attributed with the maximum temperature, wind speed and FFDI, the minimum relative humidity, and the most common categorical wind direction within them. All spatial analyses were performed in ArcGIS 10.3 [55] (data harmonization and GIS analysis) and ERDAS Imagine 2016 [56] (image processing) while statistical analysis was done in R version 3.4.0 [57] software. To provide a temporal context for the fire, non-gridded FFDI (calculated from 30-min weather data including temperature, relative humidity, wind speed, and soil moisture), and soil dryness index (both obtained from the nearby Hobart Airport and Stroud Point automatic weather stations during and before the fire event were plotted. A schematic workflow of the overall methodology is provided in Figure 2. 


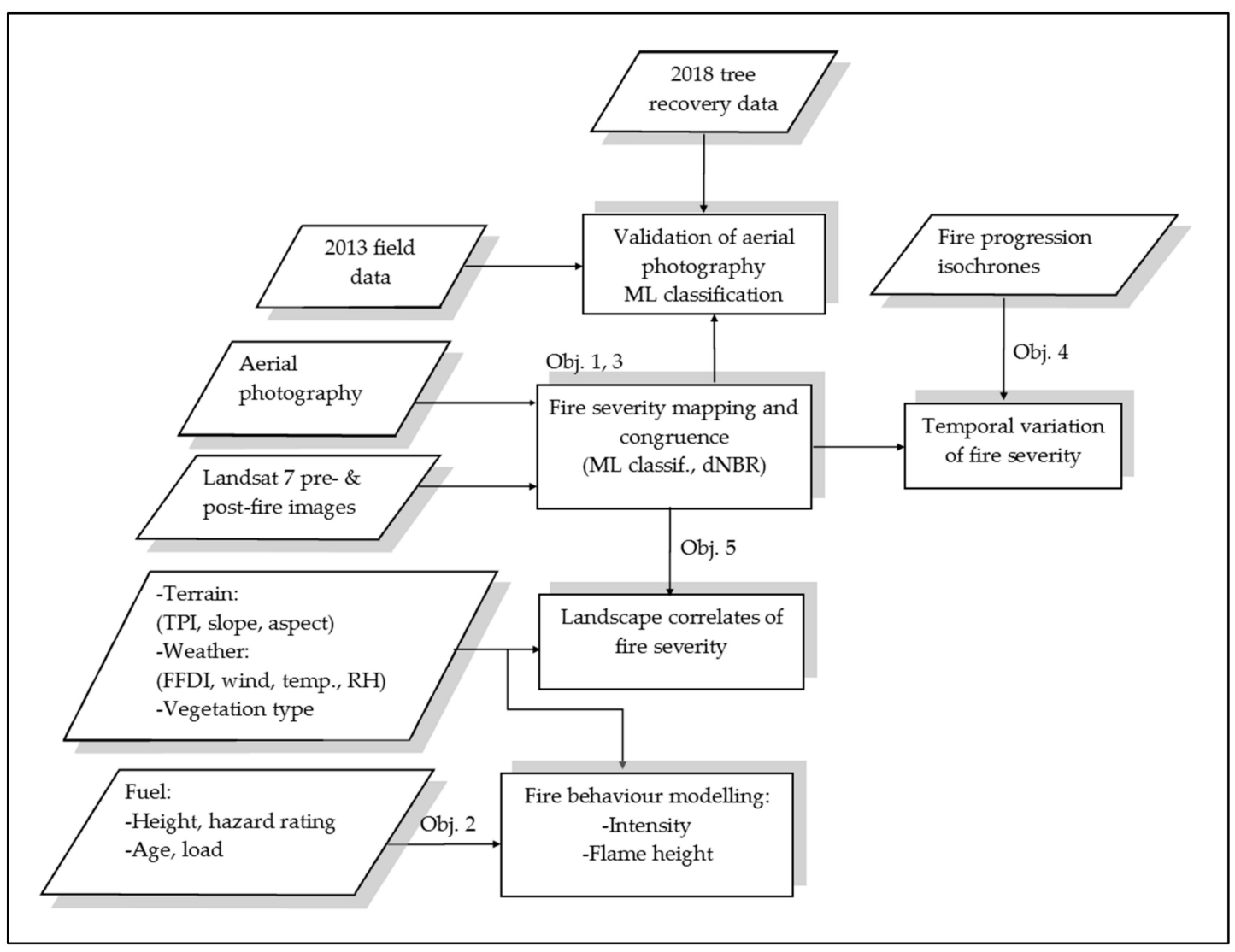

Figure 2. Schematic workflow of overall methodology of the study. For the five objectives of this study, the various data streams and analytical steps are shown, as is the way these steps are interrelated. ML refers to maximum likelihood classification; $\mathrm{RH}$ to relative humidity, and temp to temperature.

\subsubsection{Fire Behavior Modelling}

We used the Amicus modelling framework, which incorporates fire behavior models appropriate for Australian vegetation types, to estimate fire intensity and flame height of the fire [58]. We employed the dry eucalypt forest fire model (DEFFM) by Cheney et al. [59] for both dry and wet Eucalyptus forests, and forest fire behavior tables for Western Australia by Sneeuwjagt and Peet [60] to correct for wind speed in wet forests. For short rotation Eucalyptus plantations, we used DEFFM; while the pine plantation pyrometrics model by Cruz et al. [61] was used for a Pinus radiata plantation forest. A description of input parameters and equations used to calculate the rate of spread (in $\mathrm{m} \cdot \mathrm{h}^{-1}$ ) and flame height (in metres) in the mentioned models is summarized in Cruz et al. [62]. All the models use Byram's fireline intensity [12] for estimation of fire intensity (Equation (1)):

$$
F_{\text {intensity }}=H \omega R
$$

where $F_{\text {intensity }}$ is fireline intensity $\left(\mathrm{kW} \cdot \mathrm{m}^{-1}\right) ; H$ is heat yield of the available fuel $\left(\mathrm{kJ} \cdot \mathrm{kg}^{-1}\right) ; w$ is the amount of fuel consumed by flaming combustion $\left(\mathrm{kg} \cdot \mathrm{m}^{-2}\right)$; and $R$ is the forward rate of fire spread $\left(\mathrm{m} \cdot \mathrm{s}^{-1}\right)$.

Fireline intensity and flame height were estimated for four categories of gridded FFDI (low-moderate $(<12)$, high (12-24), very high (25-49), and severe (50-74) using mean estimates of surface and total fuel loads for broad vegetation types in Tasmania [63]. We used theoretical surface fuel loads (in tonnes $\cdot \mathrm{ha}^{-1}$ ) for each broad forest type on the fireground as follows: dry forest $=16.58$, wet forest $=25.56$, softwood $=16$, and hardwood $=17$. Theoretical total fuel load (surface, elevated, and bark, excluding crown fuels) in tonnes ha $^{-1}$ which we assumed were consumed, were: dry forest $=20.75$, wet forest $=31.42$, hardwood $=19$, and softwood $=18$. We used mean values of slope for each vegetation type (dry forest $=10.48^{\circ}$, wet forest $=11.04^{\circ}$, hardwood $=6.61^{\circ}$, softwood $=7.74^{\circ}$ ). 
Mean values for gridded weather data (wind speed, relative humidity $(\mathrm{RH})$, and temperature) used in the models were for each of the FFDI categories in each vegetation type. These fireline intensities and flame heights are a conservative estimate that do not include canopy fuel consumption, as no measurements of canopy fuel loads were available for these forests, nor was there a suitable canopy fire intensity model.

We calculated the aforementioned fire behavior metrics based on three assumptions: (1) that fire was spreading along flat ground (slope of $0^{\circ}$ ), (2) on a positive mean slope angle, and (3) on a downslope angle in the direction of wind. We followed the criteria of Hirsch and Martell [64] and Fernandes and Botelho [65], classifying fire intensities based on controllability as follows: intensities of $>4000 \mathrm{~kW} \cdot \mathrm{m}^{-1}$ and flame height of over $3.5 \mathrm{~m}$ were "uncontrollable," while fireline intensities of $>10,000 \mathrm{~kW} \cdot \mathrm{m}^{-1}$ and $>11.5 \mathrm{~m}$ high flames were classified as "extreme". Additionally, we report Cheney [66] categorization of fire intensity and flame height based on the degree of crown scorch, with $<500 \mathrm{~kW} \cdot \mathrm{m}^{-1}$ and $1.5 \mathrm{~m}$ flames classified as low intensity fires; $501-3000 \mathrm{~kW} \cdot \mathrm{m}^{-1}$ and $6 \mathrm{~m}$ as moderate, with complete crown scorch; 3000-7000 $\mathrm{kW} \cdot \mathrm{m}^{-1}$ and $15 \mathrm{~m}$ as crown fires in low forests; while $7000-70,000 \mathrm{~kW} \cdot \mathrm{m}^{-1}$ and $>15 \mathrm{~m}$ as complete crown fires with firestorm conditions at upper limits of fire intensity.

\subsubsection{Fire Severity Mapping}

To train the classification of aerial photography for the fire severity analysis, we used a qualitative post-fire field assessment of 53 sites undertaken by Marsden-Smedley [47] three months after the fire on 14-15 April 2013. The author stratified the fireground according to the vegetation type and severity class from visual observation of the aerial photography, with vegetation cover ranging from $0-80 \%$ depending on the severity of the burn. We excluded all nine sites belonging to the "crown unscorched class" that had undamaged crowns and only ground fires because they had a highly variable spectral signature due to the mix of burned understory and unburnt tree crowns, which were unsuitable for maximum likelihood classification. The 44 remaining sites were classified into five fire severity categories: unburnt vegetation, intermittent crown scorch, full crown scorch, intermittent crown fire, and crown fire. Unburnt represents no evidence of fire; intermittent crown scorch indicates understory fire with litter, herbs, and shrubs burnt and less than 50\% of upper canopy scorched; full crown scorch indicates 75 to $100 \%$ of upper tree canopy burnt; intermittent crown fire indicates that some leaves and twigs were consumed while the trunk was still visible; and crown fire indicates that entire tree canopy was completely consumed, resulting in charred plant remains or ash on the ground and blackened trunks.

In order to further assess the fire severity classes developed immediately after the fire, we conducted a field survey in April 2018 to determine the damage status of native Eucalyptus trees, five years after the fire. The aim of this assessment was to determine if the delayed post-fire mortality and tree response five years after the fire concorded with the immediate post-fire assessments. At each of the 36 sites sampled previously in 2013 in wet forests $(\mathrm{N}=11)$ and dry Eucalyptus forests $(\mathrm{N}=25)$ (the dominant vegetation in the region), we established a circular plot with a $10 \mathrm{~m}$ radius. Within each plot, we visually estimated the canopy cover and recorded the damage score of all Eucalyptus trees with diameter at breast height $(\mathrm{DBH})>15 \mathrm{~cm}$ using three damage categories: dead, epicormic resprouting, and unburnt. Average percentage damage and tree counts for each of the five qualitative categories of the 2013 post-fire assessment were determined. We then determined the association between the 2018 stem damage and the 2013 post fire field assessment of the Eucalyptus forests using a chi-square test.

Informed by the 2013 (and 2018) field assessments of fire severity, we used a supervised classification method, maximum likelihood (ML), to classify the aerial photo in ArcGIS 10.3 software. This was based on 133 training polygons of variable area delineated using the 2013 field data as reference, with a total extent of 250 ha: 35 unburnt polygons (total area 76 ha), 18 intermittent crown scorch (total area $3 \mathrm{ha}$ ), 20 full crown scorch (total area 28 ha), 16 intermittent crown fire (total area 39 ha), and 44 crown fire (total area $104 \mathrm{ha}$ ). These polygons did not include the 44 field sites sampled by 
Marsden-Smedley [47]. We excluded shadow as a separate class because its spectral signature was similar to very high severity class, resulting in spectral confusion between the two classes. There is therefore a likelihood that shadow was classified as very high severity class, but this is unlikely to affect our results because aerial coverage of the shadow class was negligible. We tested the accuracy of the ML classification by comparing it to Marsden-Smedley [47] 44 post-fire assessments.

We then calculated the normalised burn ratio for pre-fire and post-fire Landsat images using the method of Key and Benson [67] (Equation (2)). The index is based on the premise that fire decreases the spectral reflectance of vegetation in the NIR (band 4) and increases reflectance in the shortwave infrared (SWIR) wavelength (band 7) due to loss of vegetation moisture and increased reflectance from the exposed soil surface [68]. We computed differenced NBR (dNBR) by subtracting post-fire NBR from pre-fire NBR layer. The index ideally ranges from -2 to 2 where -2 to -0.1 denotes post-fire regrowth; 0 implies unburned, while 0-2 represents burn severity along an increasing gradient [67]. However, in real situations, the index rarely reaches these extreme values. In this study, the index ranged from -0.8 to 1.34 , although for the native Eucalyptus forests, the range was -0.1 to 1.29.

The dNBR range of values was segmented into discrete severity classes based on three approaches: (1) ranges used by Key and Benson [67] for western U.S. coniferous-dominated forests, (2) ranges we developed in this study that incorporated post-fire field assessment of the fireground, and (3) maximum likelihood classification of dNBR also based on the knowledge of the fireground. Class thresholds, borrowed from the U.S. study, included unburnt $(<0.1)$, low severity $(0.1-0.27)$, moderate severity (0.27-0.6, merged from two classes (moderate-low (0.27-0.44) and moderate-high (0.44-0.6)), high severity (0.6-0.75), and very high severity ( $>0.75)$. In this study, we first determined class thresholds by comparing the 133 training polygons with dNBR values to determine the cut-off (threshold) dNBR value for each severity class. We identified five severity classes: unburnt $(<0.2)$, low severity (0.2-0.39), moderate severity (0.39-0.53), high severity (0.53-0.75), and very high severity $(>0.75)$. The exception was the non-forest vegetation whose unburnt range extended to 0.28 . We also performed maximum likelihood (ML) classification of the raw dNBR data using training polygons that were informed by the 2013 field data. We computed the differenced normalized difference vegetation index (dNDVI) [17] whose class ranges were based on a previous assessment of fire severity in Australia's Eucalyptus-dominated forests using NDVI [10], which included unburnt $(<0.17)$, low severity (0.17-0.26), moderate severity (0.26-0.37), high severity (0.37-0.46), and very high severity $(>0.46)$. Note that the NDVI calculation (Equation (3)) is similar to NBR except that it uses band 3 (Red) instead of band 7 (SWIR), and contains similar ranges to NBR. The dNDVI in this study ranged from -0.5 to 1.34 .

$$
N B R=(\varrho 4-\varrho 7) /(\varrho 4+\varrho 7)
$$

where $\rho 4$ and $\rho 7$ are spectral reflectance in bands NIR and SWIR respectively.

$$
N D V I=(\varrho 4-\varrho 3) /(\varrho 4+\varrho 3)
$$

where $\rho 4$ and $\rho 3$ are spectral reflectance in bands NIR and Red respectively.

Temporal Patterns of Fire Severity

We determined the temporal variation of fire severity across the fireground by intersecting the fire progression isochrones with the fire severity map from aerial photographic classification. For each isochrone, we determined the total area burnt by the five fire-severity classes, and this was further broken down into each vegetation type. The duration and area of the fire isochrone that had the largest area burnt by the two highest classes was expressed as a percentage of the total duration and total area of the fireground. For each of the isochrones, we determined the maximum gridded FFDI and the maximum observed and the continuous variation of FFDI from the nearest available meteorological station. 


\subsubsection{Statistical Analysis}

Generalized linear modelling (GLM) was used to investigate the effect of environmental factors on the geographic patterns of fire severity (unsegmented dNBR). We chose to use dNBR for modelling because it provided a well-established continuous measure of fire severity, making it more amenable to modelling using linear regressions. We used a Gaussian distribution with the glm function in $\mathrm{R}$ version 3.4.0 [57] on a randomly selected subset of 2000 points derived from all vegetation types to assess geographic patterns of fire severity as a function of slope, aspect, topographic position, and the interaction of fire weather (FFDI) and vegetation type. The Akaike information criterion (AIC) [69] was adopted using the MuMIn package in R [70] to identify the most parsimonious models with $\triangle$ AIC of less than six from the best model [71]. $\triangle \mathrm{AIC}$ is the difference between the AIC of a focal model (from all combinations of predictor variables) and AIC of the best model (which has the lowest AIC). The model with the least $\triangle \mathrm{AIC}$ was repeatedly modelled 100 times with 2000 different random samples and the estimated median effect and $95 \%$ confidence interval of each parameter were subsequently determined.

We considered the post-fire multispectral aerial photography which had been ground-validated by the 2013 field data as the gold standard, for the purpose of validating the satellite classification of fire severity. For each vegetation type, the spatial congruence of aerial and satellite fire severity maps was calculated on a cell-by-cell basis by comparing classified severity categories in each cell, and then calculating the percentage of cells with matching severity category. The best satellite-based severity map (that had the highest overall classification congruence) was then selected for subsequent analysis. GLM was used to investigate the effect of slope, aspect, topographic position, and the interaction of fire weather (FFDI) and vegetation type on the probability of spatial congruence between aerial photography and the best satellite-based map of fire severity. We used a binomial distribution and logit link in R on a randomly selected subset of 2000 points. The best models were selected based on the aforementioned AIC procedure. The estimated median effect and $95 \%$ confidence interval (or uncertainty) of each variable in the best model were then determined.

\section{Results}

\subsection{Fire Weather}

Our analysis shows that the Forcett-Dunalley fire burnt 20,200 ha (excluding unburnt patches and including isolated spot fires) over 16 days from January 3 to January 18 under variable fire weather conditions, with severe to extreme forest fire danger index (FFDI 50-90) in the first two days, and achieving catastrophic levels (FFDI c. > 100) at 15:38 on January 4, 2013 (Figure 3a). At the $50 \mathrm{~m}$ grid scale, the mean (and maximum) FFDI was 34 (64) (Figure 4a), mean temperatures of $32{ }^{\circ} \mathrm{C}$ (maximum $41^{\circ} \mathrm{C}$ ), strong mean winds of $24 \mathrm{~km} \cdot \mathrm{h}^{-1}$ (maximum $54 \mathrm{~km} \cdot \mathrm{h}^{-1}$ ) from the northwest and low mean relative humidity $24 \%$ (minimum 9.6\%) (Table 1). In addition to these meteorological variables, FFDI values were also exacerbated by antecedent rainfall deficit that contributed to a steady rise in soil dryness index (SDI, where 200 represents extremely dry conditions) [72] reaching 140 prior to the fire (Figure 3b). 


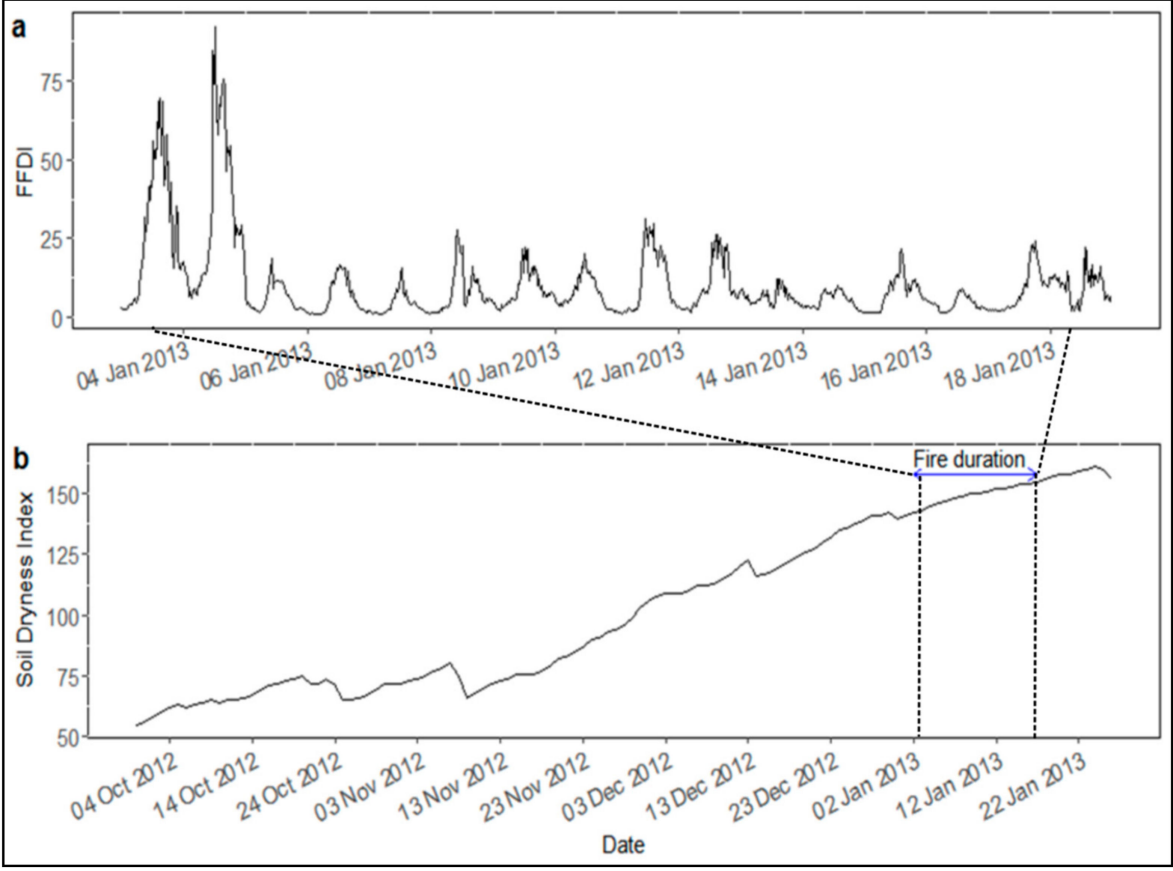

Figure 3. Temporal trends of fire weather and drought: (a) forest fire danger index (FFDI) for the duration of the fire, calculated from 30-min weather data (temperature, relative humidity, wind speed, and soil moisture) from the nearest automatic weather stations (Hobart airport and Stroud Point stations). (b) Soil dryness index (SDI) also obtained from the Australian Bureau of Meteorology, three months before and during the fire. The period of the fire is indicated by dashed lines and the double arrow.

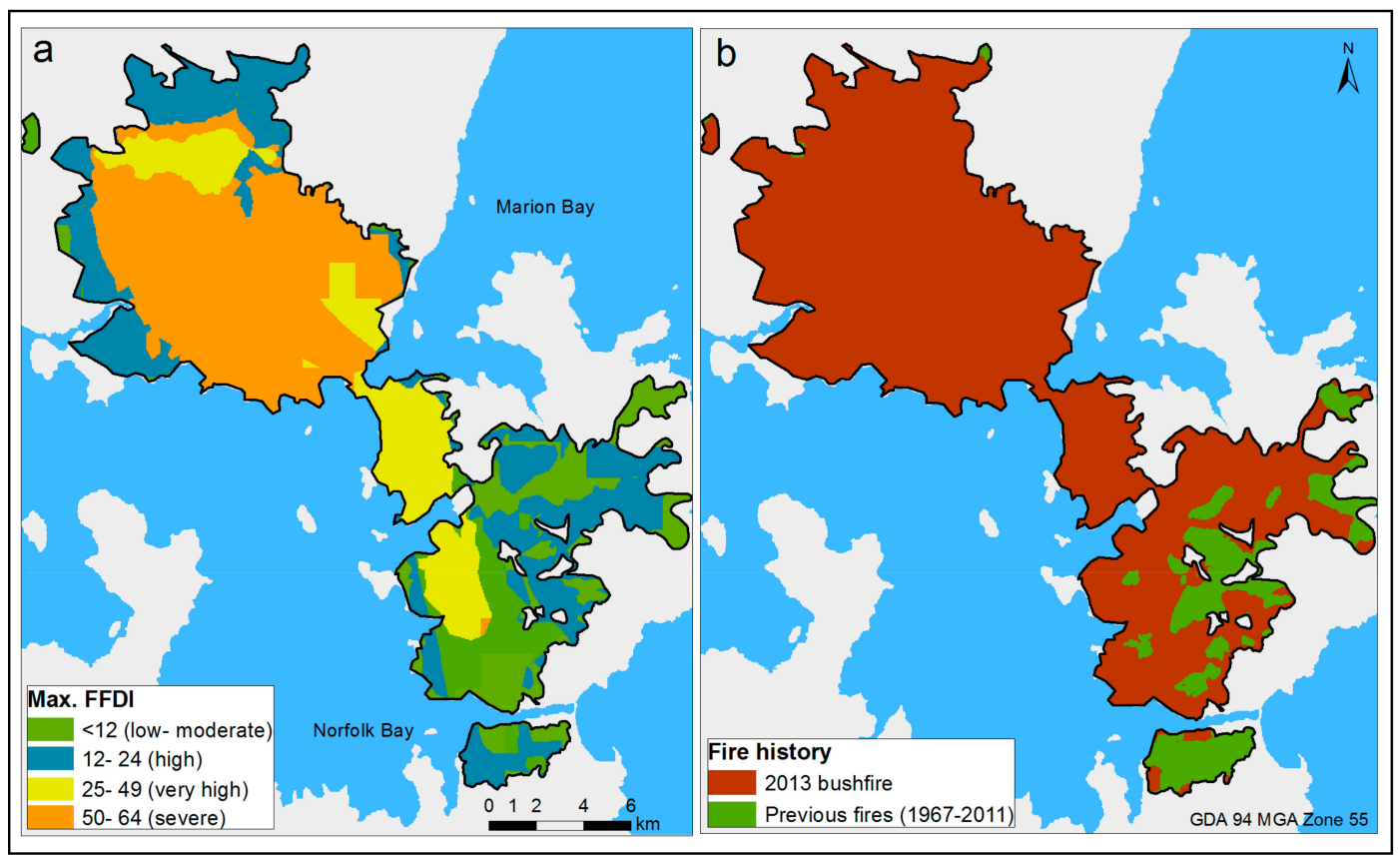

Figure 4. Environmental conditions that influenced the Forcett-Dunalley fire behavior: (a) maximum FFDI representing continuous spatial data downscaled using a numerical weather model, and (b) fire history map showing previous areas burnt by wild and prescribed fires between 1967 and 2013 and the 2013 fire perimeter. 
Table 1. Univariate statistics for meteorological variables during the fire calculated across the $50 \mathrm{~m}$ lattice of the Forcett-Dunalley fireground from hourly gridded weather data obtained from a downscaled climate analysis product [53].

\begin{tabular}{ccccc}
\hline Variable & Minimum & Mean & Maximum & Standard Deviation \\
\hline Fire Danger Index $(\mathrm{FFDI})$ & 1.7 & 34 & 63 & 20.3 \\
Temperature $\left({ }^{\circ} \mathrm{C}\right)$ & 15 & 32 & 41 & 8.4 \\
Relative Humidity $(\%)$ & 9.6 & 23.7 & 76 & 14.1 \\
Wind speed $\left(\mathrm{km} \cdot \mathrm{h}^{-1}\right)$ & 6 & 29 & 54 & 6.7 \\
\hline
\end{tabular}

\subsection{Fire Behavior}

Table 2 shows estimated mean fireline intensity and flame heights for the three idealized cases of fire spreading in the direction of the wind: (a) on a flat ground $\left(0^{\circ}\right),(\mathrm{b})$ in the upslope trajectory, and (c) in the downslope spread for each vegetation type. Extreme fireline intensities (defined here as $>10,000 \mathrm{~kW} \cdot \mathrm{m}^{-1}$ ) were estimated to occur in all forested types under severe FFDI levels when the fire was spreading on a flat ground as well as on an upslope trajectory, with the maximum estimated mean intensity reaching $68,571 \mathrm{~kW} \cdot \mathrm{m}^{-1}$ in the dry forest (Table 2). All forests, except for wet forest, were predicted to have experienced extreme intensities under downslope fire spread under very high and severe FFDI. Uncontrollable intensities (defined here as $>4000 \mathrm{~kW} \cdot \mathrm{m}^{-1}$ ) were estimated in all forests under low-moderate FFDI in flat and downslope fire spread, while extreme intensities were estimated in the upslope spread. The intensity values in the low-moderate FFDI class seem high for that class because wind speed within the fireground was particularly high in cells categorized as a low-moderate FFDI class, and within the dry Eucalyptus model (DEFFM), wind speed has a major influence on the rate of spread of a fire, thus fire intensity. Because of the geographic distribution of the vegetation types and the timing of the passage of the fire, only small areas of wet forest were burnt under severe and high FFDI conditions (Figures $1 \mathrm{a}$ and 5a).

Table 2. Estimated mean fireline intensities and flame heights in different combinations of FFDI/forest types for flat slope angles $\left(0^{\circ}\right)$, and for positive and negative mean slope angles for each forest type. $F_{\text {intensity }}$ is the fireline intensity while $F_{\text {height }}$ is the flame height. Extreme intensities following [64,65] are indicated in bold while uncontrollable intensities of $>4000 \mathrm{~kW} \cdot \mathrm{m}^{-1}$ are indicated in italics.

\begin{tabular}{|c|c|c|c|c|c|c|}
\hline Forest Type & Slope $\left({ }^{\circ}\right)$ & & Low-Moderate FFDI & High FFDI & Very High FFDI & Severe FFDI \\
\hline \multirow{6}{*}{ Dry forest } & \multirow{2}{*}{ Flat } & $F_{\text {intensity }}$ & $8363 \mathrm{~kW} \cdot \mathrm{m}^{-1}$ & 13,523 & 29,185 & 34,285 \\
\hline & & $F_{\text {height }}$ & $7.8 \mathrm{~m}$ & 11.1 & 19.4 & 21.8 \\
\hline & \multirow{2}{*}{ Upslope } & $F_{\text {intensity }}$ & 16,725 & 27,046 & 58,370 & 68,571 \\
\hline & & $F_{\text {height }}$ & 13 & 18.3 & 32.1 & 35.9 \\
\hline & \multirow{2}{*}{ Downslope } & $F_{\text {intensity }}$ & 5575 & 9015 & 19,457 & 22,857 \\
\hline & & $F_{\text {height }}$ & 5.9 & 8.3 & 14.5 & 16.2 \\
\hline \multirow{5}{*}{ Wet forest } & \multirow{2}{*}{ Flat } & $F_{\text {intensity }}$ & 4176 & 6819 & 14,174 & 14,962 \\
\hline & & $F_{\text {height }}$ & - & - & - & - \\
\hline & \multirow{2}{*}{ Upslope } & $F_{\text {intensity }}$ & 8951 & 14,616 & 30,382 & 32,072 \\
\hline & & $F_{\text {height }}$ & - & - & - & - \\
\hline & Downslope & $\begin{array}{c}F_{\text {intensity }} \\
F_{\text {height }}\end{array}$ & 2723 & 4447 & 9243 & 9757 \\
\hline \multirow{6}{*}{$\begin{array}{l}\text { Eucalyptus } \\
\text { plantation }\end{array}$} & \multirow{2}{*}{ Flat } & $F_{\text {intensity }}$ & 9426 & 15,796 & 31,316 & 34,315 \\
\hline & & $F_{\text {height }}$ & 8.4 & 12.2 & 20.0 & 21.3 \\
\hline & \multirow{2}{*}{ Upslope } & $F_{\text {intensity }}$ & 15,313 & 25,661 & 50,873 & 55,745 \\
\hline & & $F_{h e i g h t}$ & 11.9 & 17.3 & 28.3 & 30.3 \\
\hline & \multirow{2}{*}{ Downslope } & $F_{\text {intensity }}$ & 6809 & 11,410 & 22,620 & 24,786 \\
\hline & & $F_{\text {height }}$ & 6.6 & 9.6 & 15.8 & 16.9 \\
\hline \multirow{6}{*}{$\begin{array}{c}\text { Pinus } \\
\text { plantation }\end{array}$} & \multirow{2}{*}{ Flat } & $F_{\text {intensity }}$ & 2032 & 1940 & 43,070 & 42,932 \\
\hline & & $F_{h e i g h t}$ & 1.1 & 1.3 & 20.5 & 20.5 \\
\hline & \multirow{2}{*}{ Upslope } & $F_{\text {intensity }}$ & - & - & - & - \\
\hline & & $F_{\text {height }}$ & - & - & - & - \\
\hline & \multirow{2}{*}{ Downslope } & $F_{\text {intensity }}$ & - & - & - & - \\
\hline & & $F_{\text {height }}$ & - & - & - & - \\
\hline
\end{tabular}


Flame heights ranged from predicted maximums of $36 \mathrm{~m}$ in dry forest and $21 \mathrm{~m}$ in both plantation forests burning under severe FFDI, to $7 \mathrm{~m}$ flames in Eucalyptus plantation forest and $6 \mathrm{~m}$ in dry forest under low to moderate FFDI (Table 2). Flame height estimation for wet forest was not possible within the Amicus modelling framework, and the Pinus radiata plantation model [61] could not accurately simulate the influence of slope on rate of spread of the headfire under crowning conditions [73]. Consequently, fire intensity values in Pinus plantation under slope conditions were certainly erroneous, and thus the results have been excluded from Table 2. An additional factor that influenced fireline intensity was that most of the fireground (73\%) had not been previously affected by wildland fire (Figure 3b). High fuel loads in those areas probably provided enough fuel to sustain high-intensity fires that were uncontrollable during the main fire run. The undulating terrain with moderate slope angles of the fireground (mean of $9^{\circ}$ and maximum of $39^{\circ}$ ) probably affected the modelled fire line intensities (Table 2). Fire intensities and flammable heights were not calculated for non-forest vegetation.

\subsection{Fire Severity Mapping}

Comparison of the aerial photographic ML classification of fire severity with the 44 post-fire site assessments of 2013 [47] produced an overall accuracy of $90 \%$ and kappa score of 0.87 . The nine surface fire sites excluded from the training polygons were allocated to a range of severity classes depending on vegetation type, where wet forests were more likely to be classified as unburnt and dry forest as very high severity fires. The fireground, defined by the aerial photographic classification (Figure 5a), had a total area of ca. 25,950 ha, of which 5\% (1527 ha) burnt at low severities, 17\% (4486 ha) at medium severity, 32\% (8245 ha) at high severity, and 23\% (5934 ha) burnt at very high severities, while $22 \%$ (5750 ha) contained unburnt patches. Although full expression of crown burn may take up to 2-3 weeks after a fire, discrimination of the two highest severities was apparent in the aerial photography acquired immediately post-fire. Furthermore, the assessment of forest mortality 5 years after the fire corroborated the initial post-fire severity categories. A chi-square test between the 2013 qualitative assessment of fire severity and 2018 quantitative forest recovery datasets showed a strong association in dry and wet Eucalyptus forests combined $\left(\chi^{2}=406.77, p<0.001\right)$. The 2013 crown fire class had the highest percentage of resprouting (66\%) and dead trees (34\%) compared to low fire severity classes, and no fire-killed or resprouting stems occurred in the unburnt sites (Table 3). Recovering wet forests had a high canopy cover $(>80 \%)$ as it was mostly unburnt and had low severity burns, while dry forests had variable canopy cover due to variable severities, from unburnt $(>70 \%)$ to very high severity burns (0-20\%). The 2018 field survey provided evidence of the legacy effect of mixed-severity burns, as well as the unique ability of Eucalyptus species with resprouting growth forms to recover from high-intensity fires.

Fire severity patterns varied amongst vegetation types, with the highest severities occurring in dry Eucalyptus forest, Pinus plantation (that occupied a small area within the fireground), and non-forest vegetation (Table 4 and Figure 5a). Non-forests showed higher severities because their reflectance values were similar to those of severe fires in the forests. By contrast, wet forest had the largest unburnt area and smallest area burnt under extreme fire severity. During the initial days of the fire, dry sclerophyll forest in the northern sector of the fireground burnt under severe FFDI conditions, whereas most of the wet forests that dominate the southern sector and are capable of sustaining extremely intense fire intensities, burnt under lower FFDI values. 

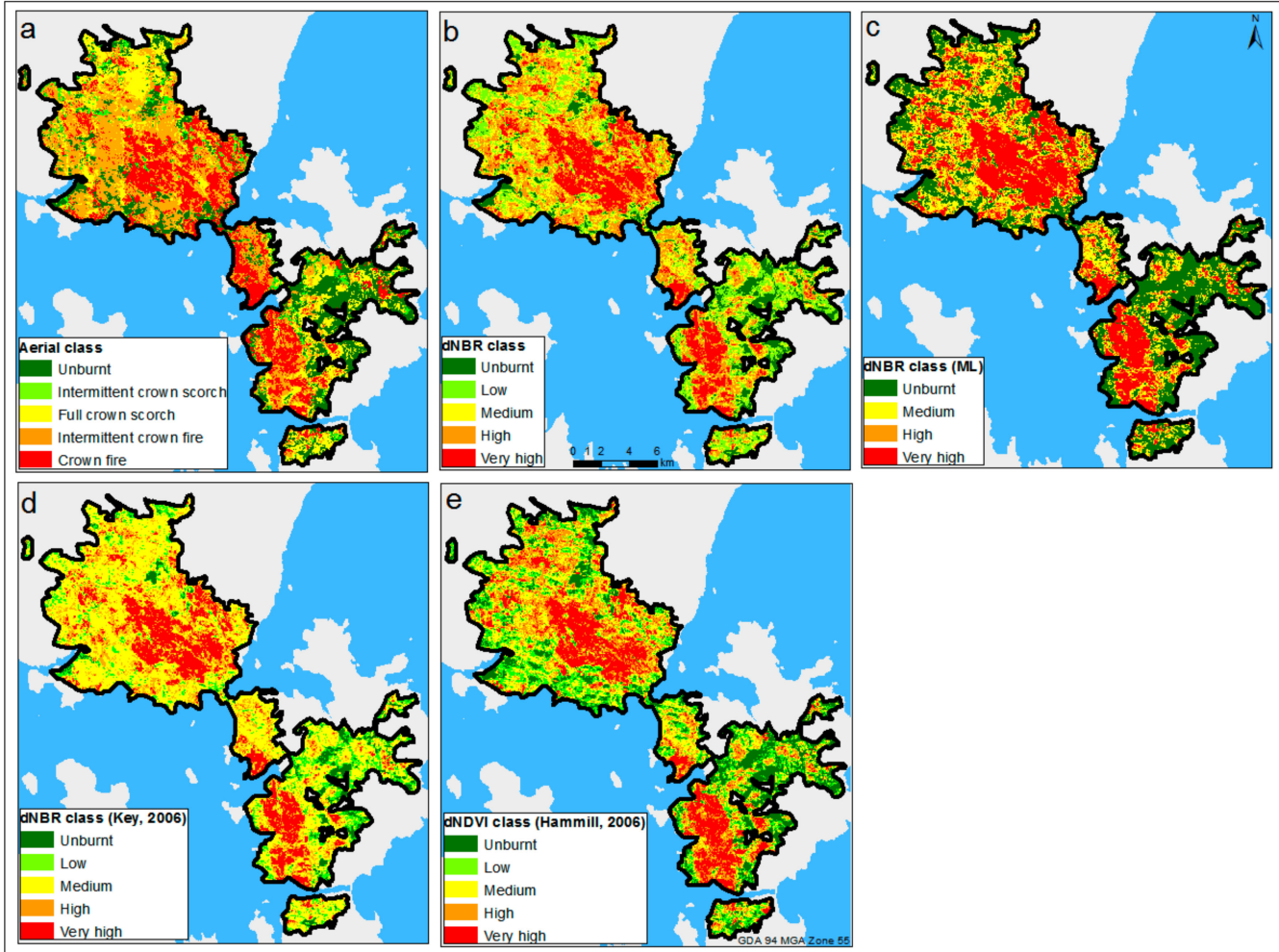

Figure 5. Fire severity maps of the fire from: (a) a classified aerial photo using maximum likelihood classification method, and (b) dNBR using class thresholds generated based on knowledge of fireground, (c) maximum likelihood classification of raw dNBR, (d) using dNBR class ranges used by Key and Benson [67] for western U.S. forests, and (e) using dNDVI class ranges used by Hammill and Bradstock [10].

Table 3. Average percentage damage (with tree counts in brackets) following the 2018 assessment of damage to Eucalyptus stems (>15 cm DBH) broken down by five qualitative categories of the 2013 post-fire assessment. The highest percentage damage score across each of the 2013 classes is indicated in bold.

\begin{tabular}{cccccc}
\hline \multirow{2}{*}{2018 Score } & \multicolumn{5}{c}{ 2013 Fire Severity Class } \\
\cline { 2 - 6 } & Unburnt & Intermittent Crown Scorch & Full Crown Scorch & Intermittent Crown Fire & Crown Fire \\
\hline Unburnt & $\mathbf{1 0 0}(38)$ & $21(7)$ & $0(0)$ & $0(0)$ & $0(0)$ \\
Epicormic & $0(0)$ & $71(75)$ & $\mathbf{9 4}(60)$ & $64(46)$ & $66(116)$ \\
resprouts & $0(0)$ & $8(4)$ & $6(4)$ & $36(31)$ & $34(49)$ \\
Dead & 38 & 86 & 64 & 77 & 165 \\
\hline No. trees & 3 & 7 & 5 & 7 & 14 \\
No. plots & 3 & & & \\
\hline
\end{tabular}

Table 4. Percentage area of each severity classes in each vegetation type in the aerial photo classification, including the unburnt class. Severity class with the highest percentage area in each vegetation type is indicated in bold. The total area of each vegetation type is indicated in hectares and as a percentage.

\begin{tabular}{lccccc}
\hline & Dry Forest & Wet Forest & Eucalypt Plantation & Pine Plantation & Non-Forest \\
\hline Unburnt & 15 & $\mathbf{5 7}$ & $\mathbf{4 0}$ & 2 & 3 \\
Low & 6 & 3 & 12 & 14 & 3 \\
Medium & 21 & 24 & 23 & 27 & 14 \\
High & $\mathbf{3 2}$ & 9 & 10 & 54 & 27 \\
Very high & 26 & 7 & 1044 & 910 & 54 \\
\hline Area in ha and \% & 15,484 & 2345 & $4 \%$ & $3 \%$ & 6158 \\
of each vegetation & $60 \%$ & $9 \%$ & & & $24 \%$ \\
\hline
\end{tabular}




\subsubsection{Temporal Patterns of Fire Severity}

The fourth isochrone (between $4 \mathrm{pm}$ and $10 \mathrm{pm}$ on the January 4,2013 ), representing $1.65 \%$ of the total duration of the fire, burnt nearly half ( $46 \%$ ) of the total area burnt from the aerial photographic analysis. During this time, $41 \%$ of all dry forest in the fireground were burnt, as well as $5 \%$ of wet forest, $73 \%$ of Eucalyptus plantation, $51 \%$ of Pinus plantation, and $65 \%$ of non-forest class. The majority of high severity ( $53 \%$ of all high severity areas) and very high severity $(59 \%)$ classes burnt in this fourth isochrone (Figures 6a and 7). Further, most vegetation types during this period experienced the largest proportion burnt by the highest severity class: $15 \%$ of all dry forest, $1 \%$ of wet forest, $9 \%$ of Eucalyptus plantation, $31 \%$ of Pinus plantation, and $12 \%$ of non-forest class (Figure 7). It is important to note that the distribution of vegetation types affects fire severity patterns. Pinus plantations are largely restricted to the area affected at the start of the fire, where wet forests were little affected (Figure 7). Over the subsequent days, fire severity was reduced significantly with an increasing proportion of both wet forests and unburnt areas in the fireground. Overall, higher fire severities were associated with more severe fire weather (i.e., higher FFDI), which peaked when FFDI was $>75$, whereas mild weather conditions led to lower fire severities and larger unburnt areas towards the end of the fire (Figure 6b).

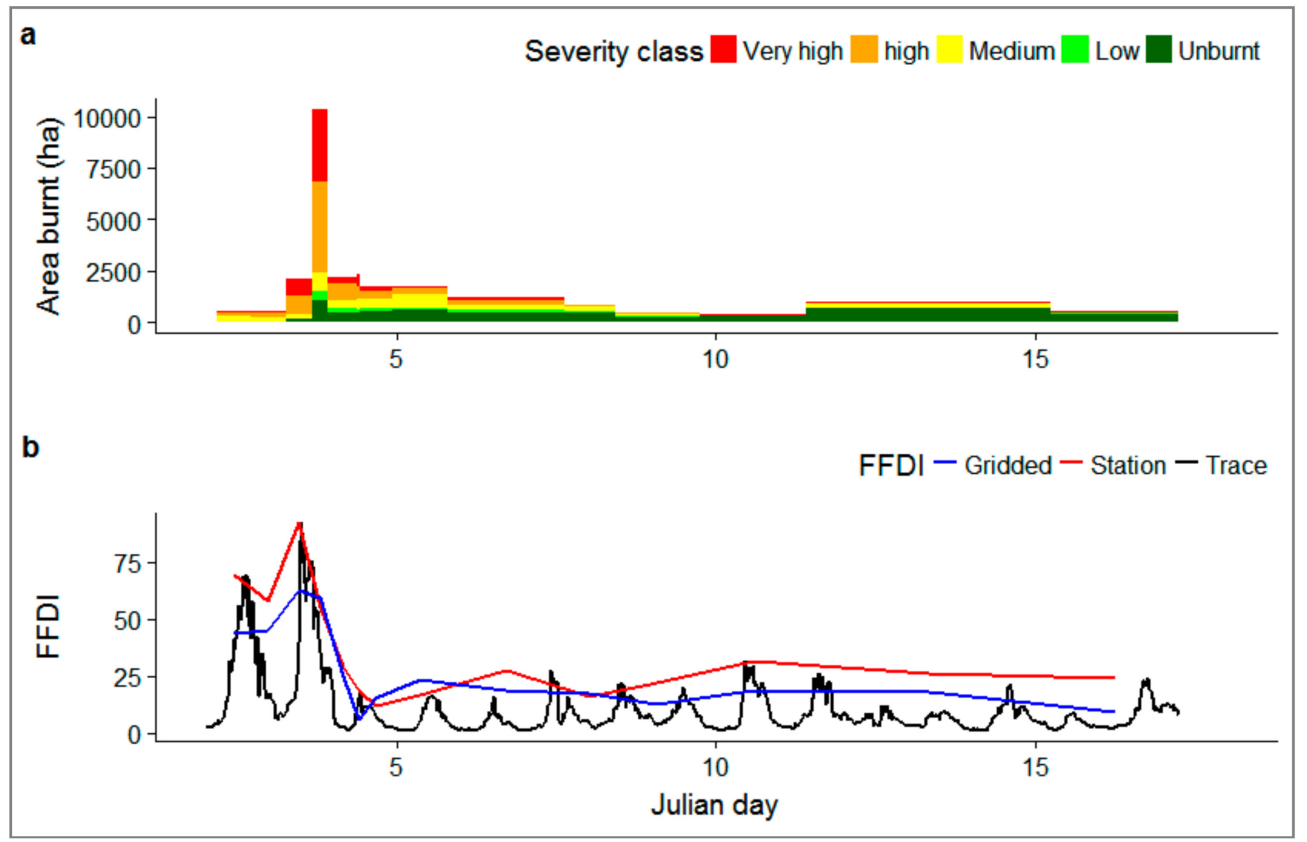

Figure 6. Summary of fire severity and fire weather during the fire. (a) Temporal variation of the five fire severity classes. The width of block in the $x$-axis corresponds to the duration of isochrone. (b) FFDI is displayed in three ways: (1) gridded FFDI corresponding with midpoint time between two consecutive fire isochrones, (2) station FFDI obtained from the nearby meteorological station, which correspond with the midpoint time between the fire isochrones, and (3) trace FFDI, which is raw FFDI as recorded at the nearby meteorological station. 


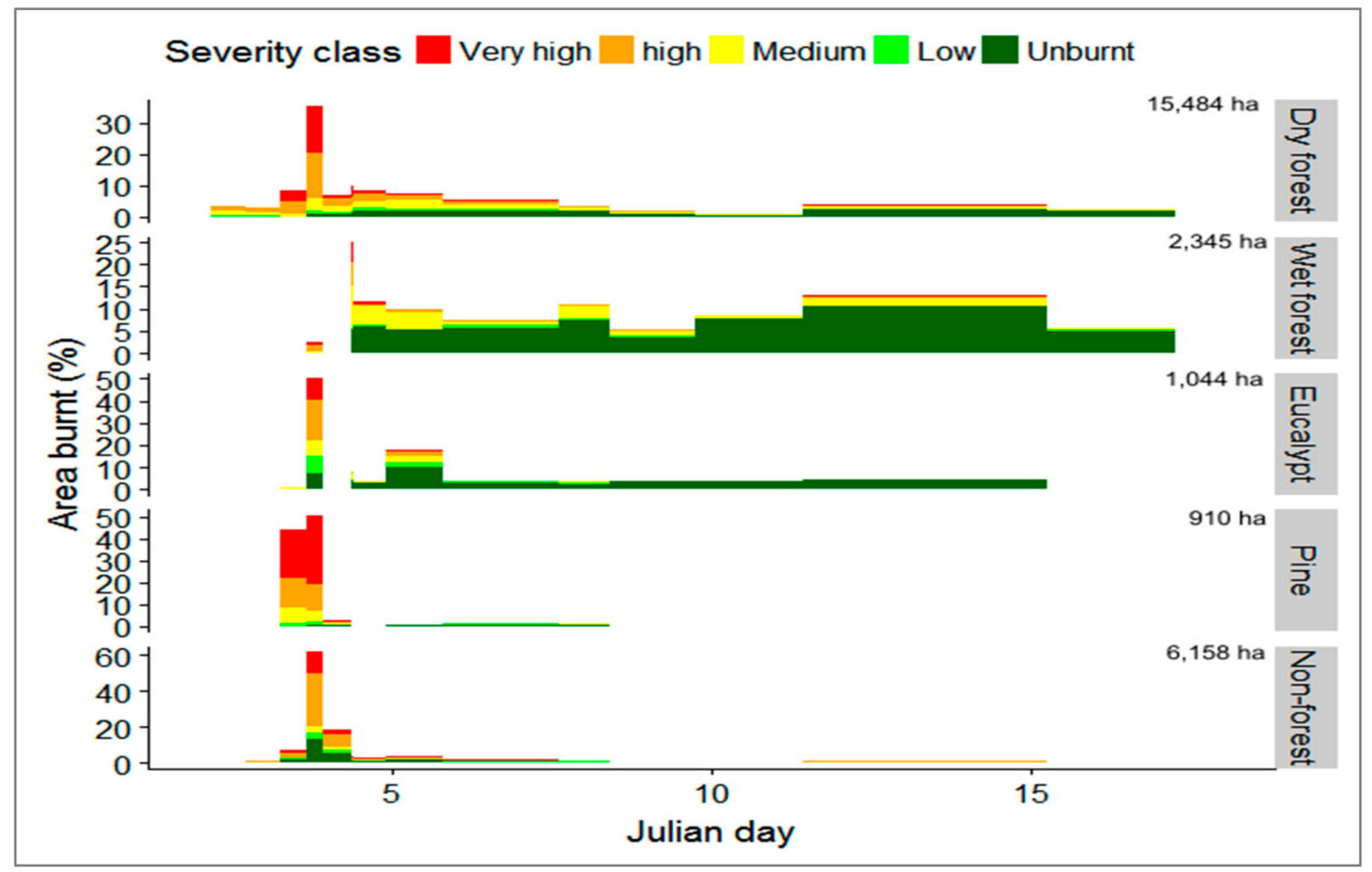

Figure 7. Temporal variation of fire severity classes stratified by different vegetation types. For each vegetation type (total area indicated on right-hand side of the graph) and the proportion (\%) of the area in each fire severity class for each isochrone is indicated.

\subsubsection{Congruence between Aerial and Satellite Fire Severity Maps}

The satellite-based maps of fire severity are broadly similar to the aerial photography maps in the very high severity class (Figure 5). Statistical analysis demonstrated that the NBR thresholds defined specifically for this study (Figure $5 b$ ) produced the highest classification accuracy compared to other approaches whose class thresholds were based on the aforementioned previous studies (Table 5). Overall accuracy of the dNBR was slightly higher than that of dNDVI across all vegetation types: dNBR had a better classification in the dry forest while dNDVI performed best in the wet forest. Class thresholds used by Key and Benson [67] (designed for coniferous vegetation) did not perform well for Eucalyptus ecosystems as evidenced by the lowest classification accuracy of all methods. Maximum likelihood classification of the raw $\mathrm{dNBR}$ using training polygons did not improve classification over our adjusted class thresholds, except in wet forest, and it failed to isolate the low severity class as a discrete class (Figure 5c). Generally, classification was higher in the wet forest than dry forest across all satellite-based fire severity approaches.

Table 5. Overall classification accuracy (\%) and kappa (in brackets) for the different approaches used to classify fire severity. Differences in class dNBR thresholds are reflected in the three dNBR approaches while we have included dNDVI for comparison to dNBR methods.

\begin{tabular}{ccccc}
\hline & $\begin{array}{c}\text { dNBR Threshold } \\
\text { (This Study) }\end{array}$ & $\begin{array}{c}\text { dNBR ML Classification } \\
\text { (This Study) }\end{array}$ & $\begin{array}{c}\text { dNBR Threshold } \\
\text { (Key \& Benson, 2006) }\end{array}$ & $\begin{array}{c}\text { dNDVI Threshold } \\
\text { (Hammill \& Bradstock, 2006) }\end{array}$ \\
\hline All vegetation & $45 \%(0.33)$ & $38 \%(0.19)$ & $34 \%(0.17)$ & $41 \%(0.26)$ \\
Dry forest & $48 \%(0.32)$ & $47 \%(0.32)$ & $36 \%(0.17)$ & $44 \%(0.29)$ \\
Wet forest & $51 \%(0.33)$ & $68 \%(0.44)$ & $33 \%(0.25)$ & $55 \%(0.36)$ \\
\hline
\end{tabular}

Breaking down the classified fire area in Figure 5a (classified aerial photography map) and Figure $5 b$ (the best dNBR map) into different vegetation types revealed comparable proportions of severity classes in each vegetation type (Figure 8). This is particularly so for dry forest as well as the 
Pinus and Eucalyptus plantations. By contrast, wet forest and non-forest vegetation had less agreement in percentage area across the severity classes. Fire severity in wet forest was over-estimated by dNBR map for the low severity classes and under-estimated for unburnt class. Fire severity in non-forest vegetation was over-estimated by dNBR for low and medium classes and under-estimated for high fire severity and unburnt areas.

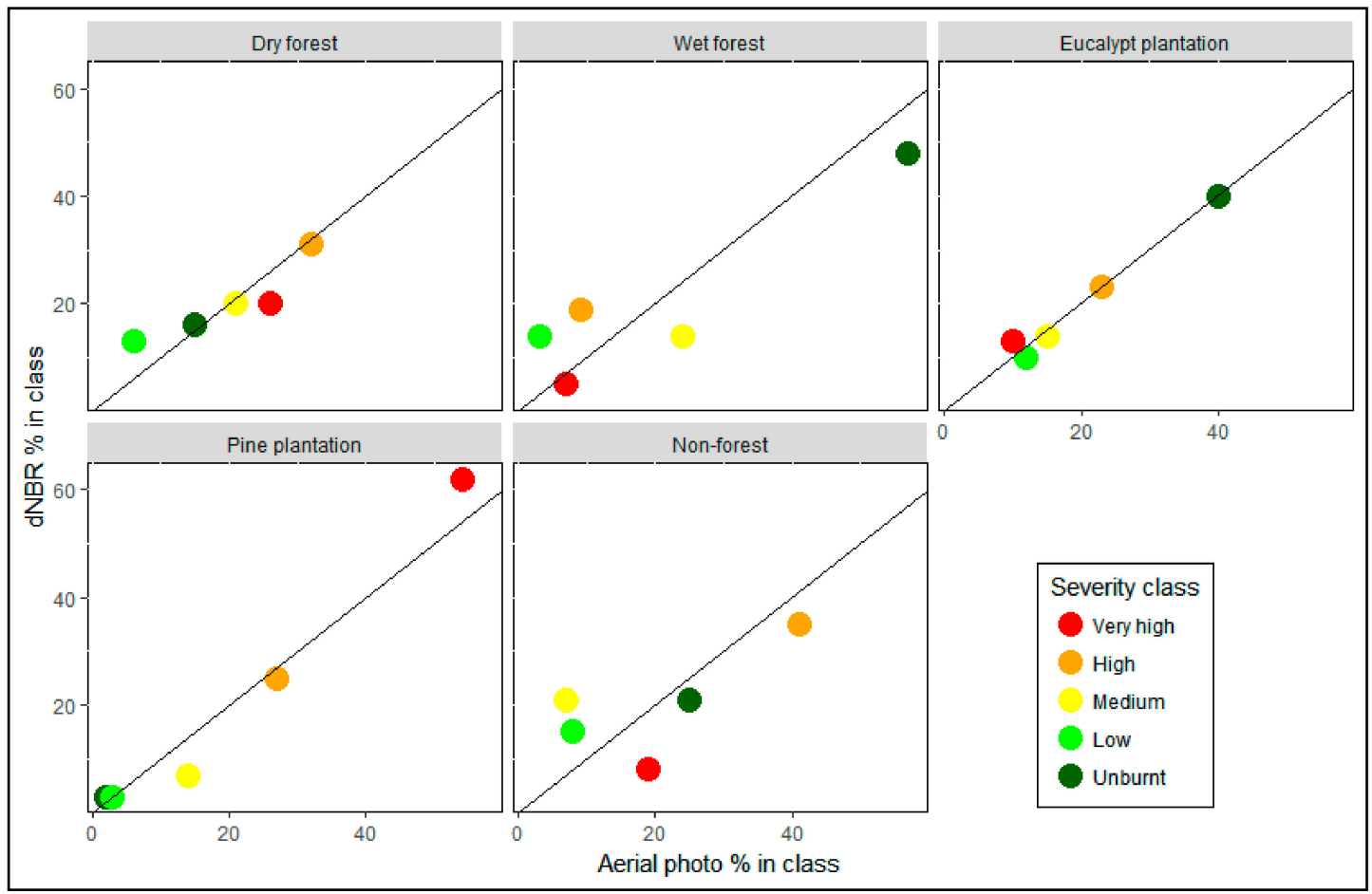

Figure 8. Scatterplot of percentage area of each severity class in each vegetation type in aerial photographic classification relative to the percentage of each class in the dNBR map. The 1:1 line shown in the graphs represents situations where corresponding points between the aerial photo and dNBR data are equal.

Spatial congruence (accuracy) between the aerial photographic and dNBR analyses varied between fire severity class and vegetation types. Overall, higher accuracies across all severity classes were observed in both wet and dry forests, while the non-forest vegetation had the least congruence. For all vegetation types, spatial congruence was highest amongst the unburnt and the two highest severity classes, while low spatial congruence occurred among the intermediate severity classes (Figure 9). For example, congruence between the two classifications in the dry forest was approximately $65 \%$ of unburnt class, $30 \%$ of low severity, and $20 \%$ of the medium severity class. This trend was also observed in the wet forest, although the accuracy for unburnt class in wet forest was higher than dry forest. 


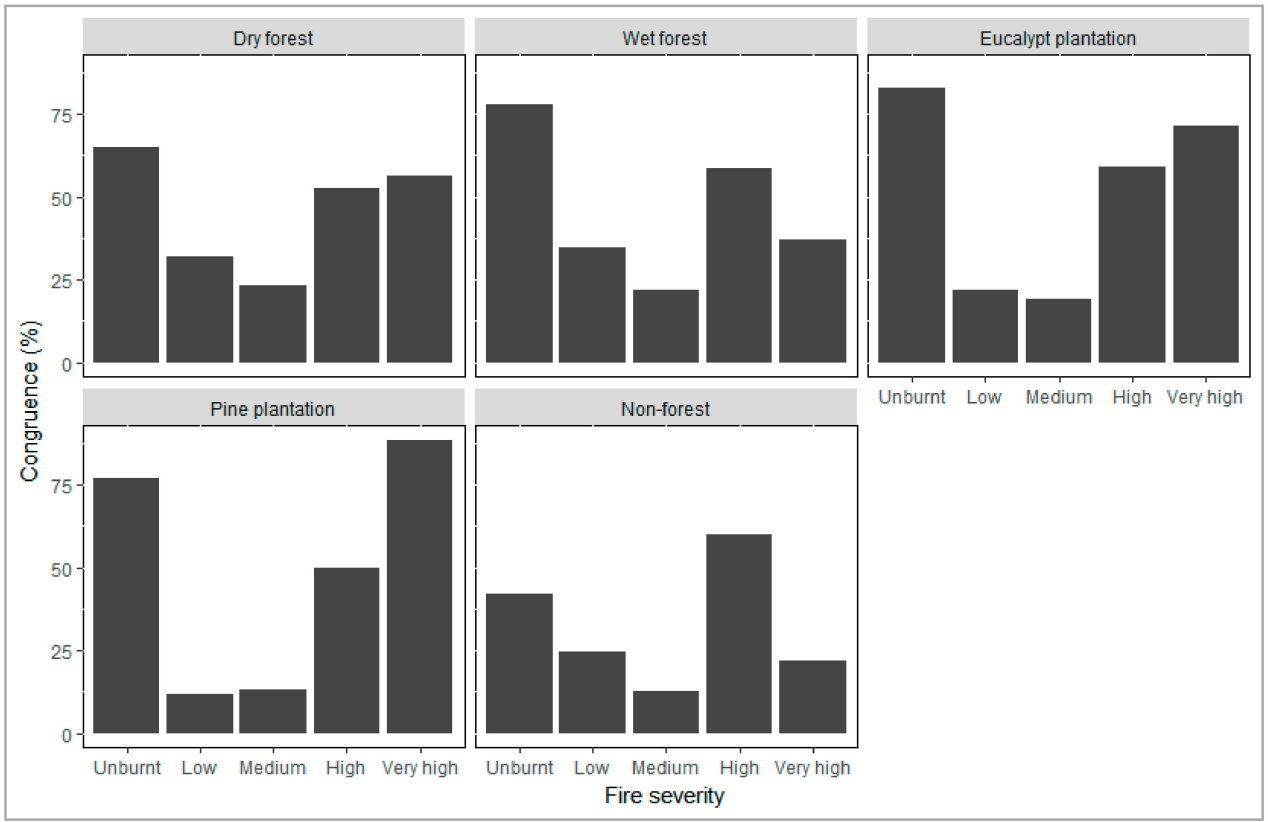

Figure 9. Per-severity class spatial congruence between aerial and dNBR satellite analysis of fire severity across the vegetation types. The $\mathrm{x}$-axis represents severity class in the dNBR map while the $\mathrm{y}$-axis is the classification accuracy (congruence) using aerial photographic classification.

\subsubsection{Statistical Results of Landscape Controls of Fire Severity}

Statistical analysis using unsegmented dNBR values revealed that the geographical patterns of fire severity are the result of the interactions between FFDI and vegetation type, as well as slope and aspect (Table 6a). We found strong evidence that fire severity differed between different vegetation types under varying fire weather conditions and between slope angles. There was some evidence of the effect of aspect, where northerly-exposed slopes were more likely to burn at higher severities than other slopes, although this was not significant (Table 7a). Slope gradient had a significant, albeit slight, negative effect on fire severity. A one-unit increase in slope angle resulted in a 0.002 unit decrease in fire severity, with steeper slopes experiencing lower fire severities than flat or moderate slopes. Interactions between FFDI and dry forest, as well as FFDI and plantation forests, had a more significant positive effect on fire severity, except for wet forest where the interactions had a negative effect, though not significant (Table 7a).

Table 6. Summary of best models from AIC analysis of environmental variables affecting: (a) fire severity, and (b) probability of classification congruence between aerial photography and satellite analysis of fire severity. Raw dNBR is the unsegmented dNBR (from -0.8 to 1.34); topo is topographic position; Cong is classification congruence.

\begin{tabular}{lcccc}
\hline \multicolumn{1}{c}{ Best Models } & ${ }^{*} K$ & $\operatorname{logLik}$ & AICc & $\Delta$ AIC \\
\hline (a) Severity: & & & & \\
Raw dNBR FFDI:Vegetation +slope + aspect & 8 & 59.7 & -103.4 & 0.00 \\
Raw dNBR FFDI:Vegetation + slope & 7 & 58.7 & -103.3 & 0.06 \\
\hline (b) Probability of classification congruence: & & & & \\
Cong FFDI:Vegetation + raw dNBR + topo & 8 & -1365.2 & 2746.4 & 0.00 \\
Cong FFDI:Vegetation + raw dNBR + aspect & 8 & -1366.5 & 2749.1 & 2.73 \\
Cong FFDI:Vegetation + raw dNBR & 7 & -1367.6 & 2749.3 & 2.95 \\
Cong FFDI:Vegetation + topo & 7 & -1368.4 & 2750.9 & 4.50 \\
\hline
\end{tabular}

${ }^{*} \mathrm{~K}$ is the number of estimated parameters; logLik is the maximum log-likelihood of each parameter; AICc is AIC corrected for small samples; and $\triangle$ AIC represents the difference between AIC of the best model from all combinations of predictor variables and the row model. Models with $\triangle$ AIC of $<6$ are shown. 
Table 7. Estimated effect of model parameters on fire severity and probability of congruence and $95 \%$ confidence interval for a linear component of Gaussian GLM (severity) and binomial GLM (probability of congruence) of the best models with $\triangle \mathrm{AIC}$ of zero selected from both AIC analyses.

\begin{tabular}{lcccc}
\hline \multicolumn{1}{c}{ Model Parameter } & Effect Estimate & Parameter Significance & $\mathbf{2 . 5 \%}$ & $\mathbf{9 7 . 5 \%}$ \\
\hline (a) Severity: & & & & \\
Slope & -0.002 & $*$ & -0.003 & -0.0002 \\
Aspect & 0.008 & $N S$ & -0.006 & 0.020 \\
FFDI: Dry forest & 0.006 & $* * *$ & 0.005 & 0.007 \\
FFDI: Wet forest & -0.001 & $N S$ & -0.004 & 0.002 \\
FFDI: Eucalypt plantation & 0.003 & $* * *$ & 0.002 & 0.005 \\
FFDI: Pine plantation & 0.009 & $* * *$ & 0.008 & 0.010 \\
FFDI: Non-forest & 0.003 & & 0.002 & 0.004 \\
\hline (b) Probability of congruence: & & $* * *$ & & \\
Degree of severity (dNBR) & 0.712 & $N S$ & 0.338 & 1.165 \\
Topographic position & -0.038 & $N S$ & -0.103 & 0.0288 \\
FFDI: Dry forest & 0.002 & $* * *$ & 0.003 & 0.007 \\
FFDI: Wet forest & 0.052 & $N S$ & -0.024 & 0.082 \\
FFDI: Eucalypt plantation & 0.008 & $* * *$ & 0.002 & 0.019 \\
FFDI: Pine plantation & 0.010 & $N S$ & -0.009 & 0.018 \\
FFDI: Non-forest & -0.003 & $* 001$ \\
\hline
\end{tabular}

*** $p<0.001,{ }^{* *} p<0.01, * p<0.05, N S=$ not significant.

Similar to fire severity analysis, interactions between FFDI and vegetation and the degree of fire severity (continuous dNBR) influenced the probability of classification congruence as both sets of variables were present in almost all the best models (Table $6 \mathrm{~b}$ ). There was strong evidence of the effect of the degree of fire severity on probability of classification congruence (Table $7 \mathrm{~b}$ ), with a higher degree of fire severity resulting in a higher probability of congruence between aerial photography and satellite analysis of fire severity. The interactions between FFDI and vegetation type were different for different vegetation classes, with interactions in dry forests not significant in influencing the probability of congruence, unlike wet forests where the interactions were significant.

From the above models, it is clear that certain combinations of fire weather (FFDI) and vegetation type contributed to differences in classification congruence with aerial photography. The highest spatial congruence between $\mathrm{dNBR}$ and aerial classification was in the wet forests (Figure 10), which was also confirmed by the best model in Table $7 \mathrm{~b}$. Classification performed better at higher fire intensities (high FFDI) in wet forest and to some degree in dry Eucalyptus forests, as well as in Pinus plantations, while low congruence was observed in low-intensity fires in those vegetation types. The lowest classification accuracy was in the low intensity fires in Pinus plantation forest. By contrast, Eucalyptus plantations and non-forest vegetation showed no difference in classification accuracy across FFDI. 


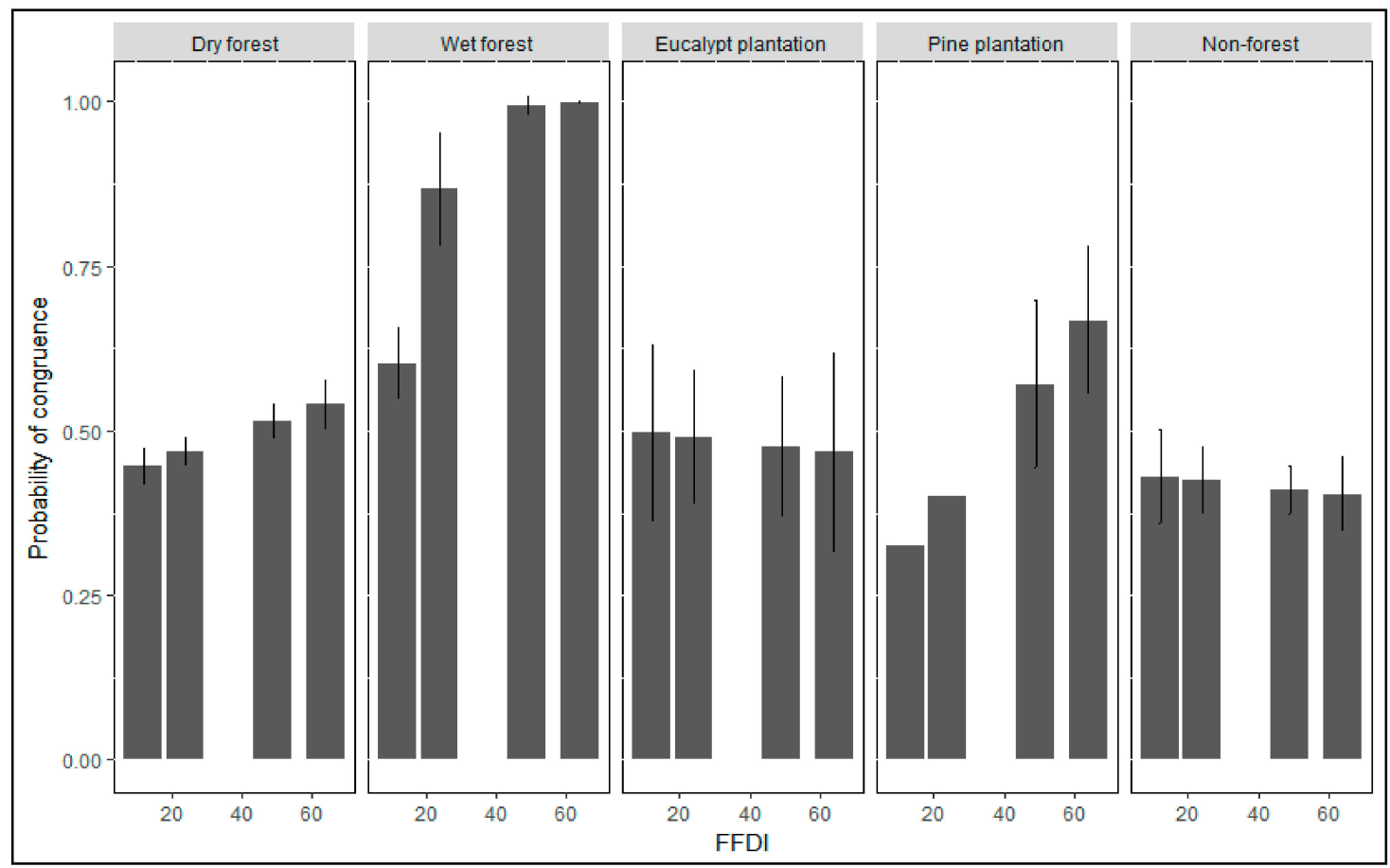

Figure 10. Predicted probability of congruence of aerial photography and dNBR maps from AIC analysis of the best model based on the interaction between vegetation and FFDI (Table 6a). The bars represent the prediction of congruence for increasing FFDI classes (low FFDI $=11$, high FFDI $=24$, very high FFDI $=49$, and severe $=64$ ).

\section{Discussion}

In this study, we have reported on fire severity and intensity patterns in the 2013 Forcett-Dunalley fire. This was a large, destructive, 16-day long fire that displayed low to extreme intensities across all forests associated with moderate (FFDI 11) to catastrophic (FFDI > 100) fire weather conditions. Using high resolution multi-spectral aerial photography (taken shortly after the fire) and using qualitative post-fire field validation data, we were able to develop a detailed map of the geographical pattern of fire severity. Fire severity and intensity were strongly controlled by the interaction of vegetation type and fire weather. We used standard Australian fire behavior equations based on regional estimates of fine and total fuel loadings for each dominant vegetation type, and estimates of prevailing weather conditions to estimate fire intensity and flame heights during the fire. According to the Amicus fire behavior model, we show that dry Eucalyptus forests probably burnt under very high fireline intensities (c. $>65,000 \mathrm{~kW} \cdot \mathrm{m}^{-1}$ ). The undulating terrain, with mean slopes $>10^{\circ}$, was found to have possibly contributed to variations in fire severity and intensity. Our detailed fire severity map presented the opportunity to assess congruence of aerial photography with several commonly applied satellite-based approaches to map fire severity. Below we contextualize our findings with respect to related studies on landscape patterns of fire severity and consider the most appropriate approach to map fire severity in temperate eucalypt forests.

The 2013 Forcett-Dunalley fire is one of the most destructive and intense fires that have impacted Australian landscapes in the last five decades and was identified as among the top 500 extreme fire events in the global analysis of Moderate Resolution Imaging Spectroradiometer (MODIS) fire radiative power between 2002 and 2013 [74]. Other comparable extreme fires in Australia include the 1967 Tasmanian fire [75], 1983 Ash Wednesday fire in South Australia [76], 2003 Canberra fire [77,78], 2003 Alpine fires in Victoria [79], 2006 Blue Mountains fires [80], and the most devastating of all, the 2009 Victorian Black Saturday fire [81]. Beyond Australia, recently similar extreme fires have mostly been reported in western United States (e.g., the 2013 Californian Rim fire [82] and 2017 North Bay fire [83]), Canada (e.g., the 2001 Chisholm fire [84]), and in the Mediterranean Basin [85]. The Forcett-Dunalley 
fire can be described as a "mega-fire" according to the criteria of Cruz et al. [81] because it involved extreme fire behavior (including wildfire-atmosphere coupling), extensive environmental damage, large area burnt (usually $>500$ ha), and property destruction, but, thankfully, there was no loss of human life. Our maximum estimates of fire intensities in dry eucalypt forests were within the accepted upper bounds of intensities for Eucalyptus forests, of approximately $70,000 \mathrm{~kW} \cdot \mathrm{m}^{-1}[66,86]$, with the 2009 Black Saturday Victorian fires reportedly achieving intensities of around $88,000 \mathrm{~kW} \cdot \mathrm{m}^{-1}$ [81]. The cause of such high fire intensities in the Forcett-Dunalley fire was a combination of high fuel loads in the long unburnt dry forest and extreme fire weather during the time of burning, as we will explain in subsequent paragraphs.

Fire severity assessments are increasingly being used by fire ecologists to understand the impacts of intense fires, and the legacy effects of prescribed burning in temperate Eucalyptus forests $[6,43,44]$. This study is the first ever to publish mapped fire severity patterns for the island state of Tasmania. The largest area of the Forcett-Dunalley fireground (55\%) exhibited the highest severities (32\% as intermittent crown fire and $23 \%$ as full crown fire). Previous studies of extreme fires in similar landscapes have shown varying total percentage area under high severities and above, such as approximately 35\% in the Blue Mountains in SE Australia [10], 49\% in 2003 Alpine fires in Victoria [79] and $67 \%$ on the first day of the 2009 Kilmore East fire in Victoria [81]. In our study, the highest severities occurred in the dry Eucalyptus forest, Pinus plantations, and non-forests (Table 4). Non-forest vegetation showed apparent higher severities because their reflectance values were similar to those of severe fires in the forests, although in reality, the fire intensity and biological impact was obviously not equivalent to that experienced in forests. Wet forest had the largest unburnt area and smallest area burnt under extreme fire severity due to its geographic location during the passage of the fire.

The temporal patterns of fire severity aligned closely with the fire weather patterns, where short-lived (six hours) extreme weather conditions produced a large percentage of the high and very high severity classes at the start of the fire. This was followed by days of moderate fire weather that resulted in a majority of the area under unburnt and low severity classes. These results are consistent with other previous studies that relate fire activity with fire weather ([22,87-90]). Few studies have examined the temporal variation of fire severity using fire isochrones within a fire event (e.g., [81,91-93]). For example, Cruz et al. [81] reported on the Black Saturday fire in February 2009 in Victoria, Australia, where most damage was produced in less than eight hours. Within that period, an intense weather system caused extreme fire to persist for two to three hours, which moderated in the subsequent hours [94]. The result was a large area burnt as crown fire (44\%) and as surface fires in different intensities (c. 50\%) while only $6 \%$ was unburnt. This 12 -h period accounts for $75 \%$ of the burned area, while the rest of the fire burned at low intensities till containment nine days later [95]. Hammill and Bradstock [88] also observed high crown consumption during extreme weather (FFDI 100), which was significantly reduced during moderate weather (FFDI 20).

Landscape patterns of variability in fire severity were clearly the product of an interplay of fire weather conditions, vegetation and fuel characteristics, and local terrain (Table 6a). The interactive effects of these environmental factors on fire regimes are complex and appear to be biome-specific [4]. For example, in Eucalyptus ecosystems of Australia, bark fuel has a greater influence on fire propagation and spotting, making fire behavior in Eucalyptus forest considerably different from other flammable forest types such as the coniferous forests of northern America [75,81]. Our study reported that vegetation type and fire weather largely influenced the spatial variability of fire severity. Fire severity was generally higher in dry forest than wet forest. Under high fire weather conditions, long unburnt dry eucalypt forests burnt at high severities due to high fuel accumulations and high vertical and horizontal fuel continuities, resulting in transmission of flames to the tree crowns. In addition, dry forests are more open and experience faster surface winds, with understory composition and condition adapted to drier conditions, making them more flammable. Lower fuel loads in frequently burnt dry forests can reduce the risk of crown fire, a key justification for fuel management in these forest types [96]. In contrast to dry forests, wet eucalypt forests that occur in cooler sheltered areas with 
high fuel and soil moistures, are only flammable under much higher fire weather conditions, and can sustain high-intensity crown fires under extreme fire weather condition [35]. Previous studies in dry and wet sclerophyll forests in Australia have identified fire weather (FFDI) as the most dominant factor influencing fire severity patterns [42,90,97]. Such intense forest fires can cause atmospheric instability resulting in a positive fire-atmosphere feedback, driving extreme fire behavior [80].

Terrain-vegetation complexes are known to affect fire severity patterns, with sheltered polar-facing slopes that support wet Eucalyptus forests less likely to burn than drier equatorial-facing slopes [98]. In our study, there was some evidence of the effect of aspect, where northerly-exposed slopes were more likely to burn at higher severities than other slopes. Slope steepness had a significant negative effect on fire severity, with steeper slopes experiencing less fire severity than flat and gentle slopes, which may be indicative of lower fuel loadings on steeper slopes. It is important to note that calculated theoretical fire intensity increased with increasing slope angles, but we were unable to determine in this study whether the observed fire severity trend with slope steepness was related to fire direction, i.e., whether fire was travelling upslope or in the downslope trajectory. Previous studies have identified a less pronounced effect of slope in dry Eucalyptus forests, albeit some studies have reported lower crown fire probability in steeper slopes due to fuel discontinuity in dry forests [37,97] similar to this study. Lecina-Diaz et al. [30] and Alexander and Cruz [99] however show that steeper slopes exhibit extreme severities due to stacking-up of crowns of large trees which increases scorching of upslope trees by hot gases, and subsequent tree crowning. Steeper positive slopes in Eucalyptus forests are known to increase rate of spread of a fire, which in turn increases flame depth, eventually inducing postfrontal crowning [66]. A confounding effect of slope and aspect is that steep equatorial facing slopes in the mid latitudes receive high solar radiation, substantially affecting the productivity of vegetation compared to polar-facing slopes [100].

Our study afforded the opportunity to compare the performance of aerial photographic mapping of fire severity with a number of well accepted satellite analyses. We found that dNBR classification based on post-fire field survey provided the highest congruence with aerial photography with a $45 \%$ agreement, outperforming dNBR using the approach of Key and Benson [16] and NDVI using the approach by Hammill and Bradstock [10]. It is clear that applying thresholds designed to work in different environments causes inaccuracies when they are applied to other environments without local calibration [4]. For instance, the site-specific dNBR had higher congruence than dNDVI, which tended to saturate at the high extremes, compared to dNBR [36], as evidenced by low dNDVI values for the high severity class, compared to dNBR range for the same severity class. In addition, dNBR was not as affected by clouds as dNDVI, making it more reliable in areas frequently affected by cloud cover. Improved performance of NBR over NDVI is consistent with findings by Escuin et al. [27]. Other studies in Australia have produced higher dNBR accuracies than reported in this study, for example, 81\% in Eucalyptus forests of the Sydney Basin in south-eastern Australia [33], 73\% in dry forests of eastern Australia [101], and 72\% and 80\% in wet and mixed Eucalyptus forests of Victoria respectively [34]. Higher accuracies in those studies were probably due to less influence of drought on spectral properties of the remotely sensed images, as well as defining separate dNBR thresholds for wet and dry Eucalyptus forests. Other studies worldwide have shown varied performance of dNBR such as $68.4 \%$ in western US coniferous forests [21], 45-88\% in boreal forests and tundra ecosystems [31], $86.4 \%$ in pine-dominated Mediterranean ecosystems [102], and low unquantified accuracy in African savannahs [24]. Higher accuracies beyond Australia were due to different forest types that respond differently to fire, and due to research, development and application of NBR in coniferous ecosystems. Developing dNBR for Eucalyptus vegetation requires further field validation of fire severity by adapting assessments such as the composite burn index [16].

In both dry and wet Eucalyptus forests, the probability of classification congruence between aerial photography and dNBR was highest for areas burnt by high-intensity fires. This is because of the distinct radiometric burn signal associated with crown defoliation, high scorch heights, charring on tree trunks, complete consumption of ground fuels and ash deposition. By contrast, low congruence in 
low-intensity wet forests was likely due to the dense canopies that obscured low-intensity fires from being detected by lower-resolution satellite sensors. Although low intensity fires in both wet and dry forests were apparent in higher resolution aerial photography, they were poorly detected by more coarse-scale satellite sensors that returned "mixels" made up of the spectral signature of undamaged crowns and burnt understories. The limited sensitivity of satellite observations in detecting low intensity burn signals in dense forests has also been reported in other studies [19,34]. Low congruence in lower intensity fires in dry forests was likely due to drought, and desiccation of live fuels, resulting in overlaps and spectral confusion between unburnt and low severity burns. Escuin et al. [27] have noted that variability in fire severity is not only influenced by changes in tree canopies but also by changes in understory vegetation and soil characteristics. The lower accuracies in low-intensity fires in dry forests are consistent with other south-eastern Australian studies of fire severity using spectral indices, such as Hammill and Bradstock [10] and Chafer et al. [37], who attributed the low accuracy to seasonal differences in vegetation condition. This is a significant limitation of dNBR in mapping low-moderate fire intensities in the dry Eucalyptus forests with open canopies. We have shown that dNBR can produce serviceable, albeit less reliable, mapping than aerial photography if dNBR thresholding is informed by aerial photography, ground assessment, and ideally, both. Further field evaluation of NBR in Eucalyptus forests is required, for example by applying the composite burn index [16] to accommodate the biophysical attributes of Eucalyptus forests.

Although ground-validated classified aerial photography provides a more precise estimation of fire severity than satellite-based measures, it is important to acknowledge that this approach also has a number of limitations. Unlike the wide spectral bandwidth of satellite imagery, the narrow spectrum of aerial photography constrains quantitative analysis and favors qualitative assessments [103]. Pre-fire conditions, such as drought, can also affect spectral signatures, confounding identification of fire effects [19]. Like satellite imagery, mixed pixels of burnt understory and unburnt tree canopies are difficult to reliably map, although there is scope to apply advanced image classification techniques that incorporate contextual information, such as object-oriented classification and machine learning methods, to help overcome these limitations. An important practical consideration is the cost of aerial photography, whereas Landsat imagery is ubiquitous and freely available.

\section{Conclusions}

This study reported on the geographic patterns of fire intensity and severity across the Forcett-Dunalley fireground using aerial photography, satellite imagery, and geographic information systems analysis of vegetation, terrain, and weather data. We have shown that fire intensity, and thus fire severity, was affected by the interplay of fire weather, vegetation, and associated fuel load, and slope angle. Under short-lived extreme FFDI conditions, about half of the fireground was burnt and large areas of dry forest burnt under very high modelled intensities (c. $>65,000 \mathrm{~kW} \cdot \mathrm{m}^{-1}$ ). The dNBR classification of Landsat imagery, based on the post-fire field survey, provided the highest $(45 \%)$ congruence with aerial photography compared to other satellite approaches. We attributed incongruence between aerial photography and satellite-based fire severity indices to an interaction between FFDI and vegetation resulting from the effect of flame height and canopy defoliation. Our study also highlighted the difficulty of accurately mapping low fire severity under dense canopies in the wet forests as well as in dry forests because of the mixed-pixel problem and misclassification of unburnt dry forests with cured understory vegetation affected by antecedent drought. We conclude that the dNBR index based on satellite imagery has potential for fire severity mapping in temperate Eucalyptus forests, but this approach requires training using aerial photography, or ground assessment, and ideally, both. 
Supplementary Materials: The following are available online at http://www.mdpi.com/2571-6255/1/3/40/s1. Figure S1: Fire perimeter map of Forcett-Dunalley fire. Figure S2: Intermittent crown scorch class on the aerial photography. Figure S3: Intermittent crown fire class on the aerial photography.

Author Contributions: M.N.N., G.J.W., and D.M.J.S.B. designed the research; M.N.N. analyzed the data, with statistical advice from G.J.W.; and M.N.N., D.M.J.S.B., and G.J.W. wrote the paper.

Funding: This research was funded by the ARC Linkage grant (LLP130100146). The provision of a PhD supplement to Mercy Ndalila from the Bushfire and Natural Hazard Cooperative Research Centre program is gratefully acknowledged.

Acknowledgments: We wish to thank Jon Marsden-Smedley, formerly from the University of Tasmania, Paul Fox-Hughes from the Bureau of Meteorology, and James Furlaud for providing technical advice and datasets for analysis. We are grateful to Ted Lefroy of TIA, University of Tasmania, for providing technical support during fieldwork; Sandra Whight and Sam Ferguson from the Tasmanian Fire service for their end-user support through the Bushfire CRC funding; and cadastral department of DPIPWE and landowners who facilitated and allowed access to their property, respectively. The support of the University of Tasmania is also acknowledged.

Conflicts of Interest: The authors declare no conflict of interest. The funders had no role in the design of the study; in the collection, analyses, or interpretation of data; in the writing of the manuscript, or in the decision to publish the results.

\section{References}

1. Cary, G.J.; Bradstock, R.A.; Gill, A.M.; Williams, R.J. Global Change and Fire Regimes in Australia; CSIRO Publishing: Collingwood, Australia, 2012.

2. Bowman, D.M.J.S.; Murphy, B.P.; Burrows, G.E.; Crisp, M.D. Fire regimes and the evolution of the Australian biota. In Flammable Australia: Fire Regimes, Biodiversity and Ecosystems in a Changing World; Bradstock, R.A., Gill, A.M.J., Williams, R., Eds.; CSIRO Publishing: Collingwood, Australia, 2012; pp. $27-47$.

3. Keeley, J.E. Fire intensity, fire severity and burn severity: A brief review and suggested usage. Int. J. Wildland Fire 2009, 18, 116-126. [CrossRef]

4. Lentile, L.B.; Holden, Z.A.; Smith, A.M.S.; Falkowski, M.J.; Hudak, A.T.; Morgan, P.; Lewis, S.A.; Gessler, P.E.; Benson, N.C. Remote sensing techniques to assess active fire characteristics and post-fire effects. Int. J. Wildland Fire 2006, 15, 319-345. [CrossRef]

5. Conard, S.G.; Sukhinin, A.I.; Stocks, B.J.; Cahoon, D.R.; Davidenko, E.P.; Ivanova, G.A. Determining effects of area burned and fire severity on carbon cycling and emissions in Siberia. Clim. Chang. 2002, 55, 197-211. [CrossRef]

6. Taylor, C.; McCarthy, M.A.; Lindenmayer, D.B. Nonlinear effects of stand age on fire severity. Conserv. Lett. 2014, 7, 355-370. [CrossRef]

7. Lindenmayer, D.B.; Blanchard, W.; McBurney, L.; Blair, D.; Banks, S.C.; Driscoll, D.; Smith, A.L.; Gill, A.M. Fire severity and landscape context effects on arboreal marsupials. Biol. Conserv. 2013, 167, 137-148. [CrossRef]

8. Price, O.; Bradstock, R. Landscape scale influences of forest area and housing density on house loss in the 2009 Victorian bushfires. PLoS ONE 2013, 8, e73421. [CrossRef] [PubMed]

9. Perez-Cabello, F.; Echeverria, M.T.; Ibarra, P.; de la Riva, J. Effects of fire on vegetation, soil and hydrogeomorphological behaviour in Mediterranean Ecosystems. In Remote Sensing of Burn Severity. Earth Observation of Wildland Fires in Mediterranean Ecosystems; Chuvieco, E., Ed.; Springer: Berlin/Heidelberg, Germany, 2009; pp. 111-170.

10. Hammill, K.A.; Bradstock, R.A. Remote sensing of fire severity in the Blue Mountains: Influence of vegetation type and inferring fire intensity. Int. J. Wildland Fire 2006, 15, 213-226. [CrossRef]

11. Cochrane, M.A.; Alencar, A.; Schulze, M.D.; Souza, C.M.; Nepstad, D.C.; Lefebvre, P.; Davidson, E.A. Positive feedbacks in the fire dynamic of closed canopy tropical forests. Science 1999, 284, 1832-1835. [CrossRef] [PubMed]

12. Byram, G.M. Combustion of forest fuels. In Forest Fire Control and Use; Davis, K.P., Ed.; McGraw-Hill: NewYork, NY, USA, 1959; pp. 61-89.

13. Noble, J. Behaviour of a very fast grassland wildfire on the riverine plain of Southeastern Australia. Int. J. Wildland Fire 1991, 1, 189-196. [CrossRef] 
14. Keane, R.E.; Morgan, P.M.; Dillon, G.K.; Sikkink, P.G.; Karau, E.C.; Holden, Z.A.; Drury, S.A. A Fire Severity Mapping System for RealTime Fire Management Applications and LongTerm Planning: The FIRESEV Project; JFSP Research Project Reports. JFSP-09-1-07-4; JFSP: Boise, ID, USA, 2013.

15. Loschiavo, J.; Cirulis, B.; Zuo, Y.; Hradsky, B.A.; Di Stefano, J. Mapping prescribed fire severity in south-east Australian eucalypt forests using modelling and satellite imagery: A case study. Int. J. Wildland Fire 2017, 26, 491-497. [CrossRef]

16. Key, C.H.; Benson, N. Landscape Assessment (LA). FIREMON: Fire Effects Monitoring and Inventory System; U.S. Department of Agriculture, Forest Service, Rocky Mountain Research Station: Fort Collins, CO, USA, 2006; p. LA-1-55.

17. Rouse, J.W., Jr.; Haas, R.; Schell, J.; Deering, D. Monitoring Vegetation Systems in the Great Plains with ERTS; Texas A\&M Univ.: College Station, TX, USA, 1974.

18. Van Wagtendonk, J.W.; van Wagtendonk, K.A.; Thode, A.E. Factors associated with the severity ofintersecting fires in Yosemite National Park, California, US. Fire Ecol. 2012, 8, 11-31. [CrossRef]

19. Miller, J.D.; Thode, A.E. Quantifying burn severity in a heterogeneous landscape with a relative version of the delta Normalized Burn Ratio (dNBR). Remote Sens. Environ. 2007, 109, 66-80. [CrossRef]

20. Picotte, J.J.; Peterson, B.E.; Meier, G.; Howard, S.M. 1984-2010 trends in fire burn severity and area for the conterminous US. Int. J. Wildland Fire 2016, 25, 413-420. [CrossRef]

21. Parks, S.; Dillon, G.; Miller, C. A new metric for quantifying burn severity: The Relativized Burn Ratio. Remote Sens. 2014, 6, 1827-1844. [CrossRef]

22. Lydersen, J.M.; North, M.P.; Collins, B.M. Severity of an uncharacteristically large wildfire, the Rim Fire, in forests with relatively restored frequent fire regimes. For. Ecol. Manag. 2014, 328, 326-334. [CrossRef]

23. Coppoletta, M.; Merriam, K.E.; Collins, B.M. Post-fire vegetation and fuel development influences fire severity patterns in reburns. Ecol. Appl. 2016, 26, 686-699. [CrossRef] [PubMed]

24. Smith, A.M.S.; Wooster, M.J.; Drake, N.A.; Dipotso, F.M.; Falkowski, M.J.; Hudak, A.T. Testing the potential of multi-spectral remote sensing for retrospectively estimating fire severity in African Savannahs. Remote Sens. Environ. 2005, 97, 92-115. [CrossRef]

25. Roy, D.P.; Boschetti, L.; Trigg, S.N. Remote Sensing of fire severity: Assessing the performance of the Normalized Burn Ratio. IEEE Geosci. Remote Sens. 2006, 3, 112-116. [CrossRef]

26. Edwards, A.C.; Maier, S.W.; Hutley, L.B.; Williams, R.J.; Russell-Smith, J. Spectral analysis of fire severity in north Australian tropical savannas. Remote Sens. Environ. 2013, 136, 56-65. [CrossRef]

27. Escuin, S.; Navarro, R.; Fernandez, P. Fire severity assessment by using NBR (Normalized Burn Ratio) and NDVI (Normalized Difference Vegetation Index) derived from LANDSAT TM/ETM images. Int. J. Remote Sens. 2008, 29, 1053-1073. [CrossRef]

28. Oliveras, I.; Gracia, M.; More, G.; Retana, J. Factors influencing the pattern of fire severities in a large wildfire under extreme meteorological conditions in the Mediterranean basin. Int. J. Wildland Fire 2009, 18, 755-764. [CrossRef]

29. Lozano, F.J.; Suárez-Seoane, S.; de Luis, E. Assessment of several spectral indices derived from multi-temporal Landsat data for fire occurrence probability modelling. Remote Sens. Environ. 2007, 107, 533-544. [CrossRef]

30. Lecina-Diaz, J.; Alvarez, A.; Retana, J. Extreme fire severity patterns in topographic, convective and wind-driven historical wildfires of Mediterranean pine forests. PLoS ONE 2014, 9, e85127. [CrossRef] [PubMed]

31. Allen, J.L.; Sorbel, B. Assessing the differenced Normalized Burn Ratios ability to map burn severity in the boreal forest and tundra ecosystems of Alaskas national parks. Int. J. Wildland Fire 2008, 17, 463-475. [CrossRef]

32. Hall, R.J.; Freeburn, J.T.; de Groot, W.J.; Pritchard, J.M.; Lynham, T.J.; Landry, R. Remote sensing of burn severity: Experience from western Canada boreal fires. Int. J. Wildland Fire 2008, 17, 476-489. [CrossRef]

33. Chafer, C.J. A comparison of fire severity measures: An Australian example and implications for predicting major areas of soil erosion. Catena 2008, 74, 235-245. [CrossRef]

34. Tanase, M.A.; Kennedy, R.; Aponte, C. Fire severity estimation from space: A comparison of active and passive sensors and their synergy for different forest types. Int. J. Wildland Fire 2015, 24, 1062-1075. [CrossRef]

35. Clarke, P.J.; Knox, K.J.E.; Bradstock, R.A.; Munoz-Robles, C.; Kumar, L. Vegetation, terrain and fire history shape the impact of extreme weather on fire severity and ecosystem response. J. Veg. Sci. 2014, 25, 1033-1044. [CrossRef] 
36. Boer, M.M.; Macfarlane, C.; Norris, J.; Sadler, R.J.; Wallace, J.; Grierson, P.F. Mapping burned areas and burn severity patterns in SW Australian eucalypt forest using remotely-sensed changes in leaf area index. Remote Sens. Environ. 2008, 112, 4358-4369. [CrossRef]

37. Chafer, C.J.; Noonan, M.; Macnaught, E. The post-fire measurement of fire severity and intensity in the Christmas 2001 Sydney wildfires. Int. J. Wildland Fire 2004, 13, 227-240. [CrossRef]

38. Greg, M.; Kangmin, M.; Luke, S. Mapping fire severity and fire extent in forest in Victoria for ecological and fuel outcomes. Ecol. Manag. Restor. 2017, 18, 54-65.

39. Demaria, E.M.C. Challenges of Remote Sensing validation. In Earth Observation for Water Resources Management: Current Use and Future Opportunities for the Water Sector; World Bank: Washington, DC, USA, 2016; pp. 167-171.

40. Soto-Berelov, M.; Jones, S.; Farmer, E.; Woodgate, W. Review of validation standards of Earth Observation derived biophysical products. In AusCover Good Practice Guidelines: A Technical Handbook Supporting Calibration and Validation Activities of Remotely Sensed Data Products, 11th ed.; Held, A., Phinn, S., Soto-Berelov, M., Jones, S., Eds.; TERN AusCover: Canberra, Australia, 2015.

41. Barrett, T.W. Modelling burn severity for the 2003 NSW/ACT wildfires using Landsat imagery. In Proceedings of the Bushfire Conference 2006. Life In A Fire-Prone Environment: Translating Science Into Practice, Brisbane, Australia, 6-9 June 2006.

42. Storey, M.; Price, O.; Tasker, E. The role of weather, past fire and topography in crown fire occurrence in eastern Australia. Int. J. Wildland Fire 2016, 25, 1048-1060. [CrossRef]

43. Bowman, D.M.; Williamson, G.J.; Prior, L.D.; Murphy, B.P. The relative importance of intrinsic and extrinsic factors in the decline of obligate seeder forests. Glob. Ecol. Biogeogr. 2016, 25, 1166-1172. [CrossRef]

44. Bassett, O.D.; Prior, L.D.; Slijkerman, C.M.; Jamieson, D.; Bowman, D.M.J.S. Aerial sowing stopped the loss of alpine ash (Eucalyptus delegatensis) forests burnt by three short-interval fires in the Alpine National Park, Victoria, Australia. For. Ecol. Manag. 2015, 342, 39-48. [CrossRef]

45. Hill, K.J.; Santoso, A.; England, M.H. Interannual Tasmanian rainfall variability associated with large-scale climate modes. J. Clim. 2009, 22, 4383-4397. [CrossRef]

46. Bureau of Meteorology. 2013 Tasmanian Bushfires Inquiry; Bureau of Meteorology: Hobart, Australia, 2013.

47. Marsden-Smedley, J. Tasmanian Wildfires January-February 2013: Forcett-Dunalley, Repulse, Bicheno, Giblin River, Montumana, Molesworth and Gretna; Bushfire Cooperative Research Centre: East Melbourne, Australia, 2014.

48. Firestorm: The story of the bushfire at Dunalley. The Guardian, 23 May 2013. Available online: https://www. theguardian.com/world/interactive/2013/may/26/firestorm-bushfire-dunalley-holmes-family (accessed on 21 June 2018).

49. Kitchener, A.; Harris, S. From Forest to Fjaeldmark: Descriptions of Tasmania's Vegetation; Department Of Primary Industries Parks Water \& Environment: Tasmania, Australia, 2013.

50. United States Geological Survey. SLC-Off Products: Background. Available online: https://landsat.usgs.gov / slc-products-background (accessed on 2 May 2018).

51. Hijmans, R.J. Raster: Geographic Data Analysis and Modeling. R Package Version 2.5-8. Available online: https: / CRAN.R-project.org/package=raster (accessed on 2 June 2016).

52. Weiss, A. Topographic position and landforms analysis. Presented at the ESRI User Conferencee, San Diego, CA, USA, 9-13 July 2001. Available online: http:/ / www.jennessent.com/downloads/TPI-poster-TNC_18x2 2.pdf (accessed on 13 September 2018).

53. Jakob, D.; Su, C.-H.; Eizenberg, N.; Kociuba, G.; Steinle, P.; Fox-Hughes, P.; Bettio, L. An atmospheric high-resolution regional reanalysis for Australia. Bull. Aust. Meteorol. Oceanogr. Soc. 2017, 30, 16-23.

54. Bureau of Meteorology. Maps and Gridded Spatial Data. Available online: http://www.bom.gov.au/clima te/data-services/maps.shtml (accessed on 3 May 2018).

55. ESRI. ArcGIS Desktop: Release 10.3; Environmental Systems Research Institute: Redlands, CA, USA, 2015.

56. Hexagon Geospatial. ERDAS Imagine 2016; Hexagon AB: Stockholm, Sweden, 2016.

57. R Core Team. R: A Language and Environment for Statistical Computing; R Foundation for Statistical Computing: Vienna, Austria, 2017.

58. Plucinski, M.P.; Sullivan, A.L.; Rucinski, C.J.; Prakash, M. Improving the reliability and utility of operational bushfire behaviour predictions in Australian vegetation. Environ. Model. Softw. 2017, 91, 1-12. [CrossRef]

59. Cheney, N.P.; Gould, J.S.; McCaw, W.L.; Anderson, W.R. Predicting fire behaviour in dry eucalypt forest in southern Australia. For. Ecol. Manag. 2012, 280, 120-131. [CrossRef] 
60. Sneeuwjagt, R.J.; Peet, G.B. Forest Fire Behaviour Tables for Western Australia, 3rd ed.; Department of Conservation and Land Management: Perth, Australia, 1985.

61. Cruz, M.G.; Alexander, M.E.; Fernandes, P.A.M. Development of a model system to predict wildfire behaviour in pine plantations. Aust. For. 2008, 71, 113-121. [CrossRef]

62. Cruz, M.G.; Gould, J.S.; Alexander, M.E.; Sullivan, A.L.; McCaw, W.L.; Matthews, S. A Guide to Rate of Fire Spread Models for Australian Vegetation; CSIRO Land and Water Flagship: Canberra, Australia; AFAC: Melbourne, Australia, 2015.

63. Bresnehan, S.J. An Assessment of Fuel Characteristics and Fuel Loads in the Dry Sclerophyll Forests of South-East Tasmania. Ph.D. Thesis, University of Tasmania, Hobart, Australia, 2003.

64. Hirsch, K.; Martell, D. A Review of initial attack fire crew productivity and effectiveness. Int. J. Wildland Fire 1996, 6, 199-215. [CrossRef]

65. Fernandes, P.M.; Botelho, H.S. A review of prescribed burning effectiveness in fire hazard reduction. Int. J. Wildland Fire 2003, 12, 117-128. [CrossRef]

66. Cheney, N.P. Predicting Forest Fire Behaviour-The Australian Experienc; The U.S. Man and the Biosphere Program: Paris, France, 1991.

67. Key, C.H.; Benson, N.C. Landscape Assessment (LA) sampling and analysis methods. In Fire Effects Monitoring and Inventory System; Lutes, D.C., Keane, R.E., Caratti, J.F., Key, C.H., Benson, N.C., Sutherland, S., Gangi, L.J., Eds.; USDA Forest Service, Rocky Mountain Research Station: Ogden, UT, USA, 2006; pp. 1-51.

68. Lutes, D.C.; Keane, R.E.; Caratti, J.F.; Key, C.H.; Benson, N.C.; Sutherland, S.; Gangi, L.J. FIREMON: Fire Effects Monitoring and Inventory System; U.S. Department of Agriculture, Forest Service, Rocky Mountain Research Station: Fort Collins, CO, USA, 2006.

69. Burnham, K.P.; Anderson, D.R. Model Selection and Inference: A Practical Information-Theoretic Approach, 2nd ed.; Springer: New York, NY, USA, 2002.

70. Barton, K. MuMIn: Multi-Model Inference. R Package Version 1.40.4. Available online: https://CRAN.R-p roject.org $/$ package=MuMIn (accessed on 30 January 2018).

71. Richards, S.A.; Whittingham, M.J.; Stephens, P.A. Model selection and model averaging in behavioural ecology: The utility of the IT-AIC framework. Behav. Ecol. Sociobiol. 2011, 65, 77-89. [CrossRef]

72. Finkele, K.; Mills, G.A. National gridded drought factors and comparison of two soil moisture deficit formulations used in prediction of Forest Fire Danger Index in Australia. Aust. Meteorol. Mag. 2006, 55, 183-197.

73. CSIRO. Amicus Version 0.5 beta Users' Guide; CSIRO: Canberra, Australia, 2016.

74. Bowman, D.M.J.S.; Williamson, G.J.; Abatzoglou, J.T.; Kolden, C.A.; Cochrane, M.A.; Smith, A.M.S. Human exposure and sensitivity to globally extreme wildfire events. Ecol. Evol. 2017, 1, 0058. [CrossRef] [PubMed]

75. Luke, R.H.; McArthur, A.G. Bushfires in Australia; Australian Government Publishing Service for CSIRO: Canberra, Australia, 1978.

76. Keeves, A.; Douglas, D.R. Forest fires in South Australia on 16 February 1983 and consequent future forest management aims. Aust. For. 1983, 46, 148-162. [CrossRef]

77. Mitchell, R.M.; O'Brien, D.M.; Campbell, S.K. Characteristics and radiative impact of the aerosol generated by the Canberra firestorm of January 2003. J. Geophys. Res. Atmos. 2006, 111. [CrossRef]

78. Fromm, M.; Tupper, A.; Rosenfeld, D.; Servranckx, R.; McRae, R. Violent pyro-convective storm devastates Australia's capital and pollutes the stratosphere. Geophys. Res. Lett. 2006, 33. [CrossRef]

79. Tolhurst, K.G.; McCarthy, G. Effect of prescribed burning on wildfire severity: A landscape-scale case study from the 2003 fires in Victoria. Aust. For. 2016, 79, 1-14. [CrossRef]

80. McRae, R.H.D.; Sharples, J.J.; Fromm, M. Linking local wildfire dynamics to pyroCb development. Nat. Hazards Earth Syst. Sci. 2015, 15, 417-428. [CrossRef]

81. Cruz, M.G.; Sullivan, A.L.; Gould, J.S.; Sims, N.C.; Bannister, A.J.; Hollis, J.J.; Hurley, R.J. Anatomy of a catastrophic wildfire: The Black Saturday Kilmore East fire in Victoria, Australia. For. Ecol. Manag. 2012, 284, 269-285. [CrossRef]

82. Peterson, D.A.; Hyer, E.J.; Campbell, J.R.; Fromm, M.D.; Hair, J.W.; Butler, C.F.; Fenn, M.A. The 2013 Rim Fire: Implications for predicting extreme fire spread, pyroconvection, and smoke Emissions. Bull. Am. Meteorol. Soc. 2014, 96, 229-247. [CrossRef] 
83. Nauslar, N.; Abatzoglou, J.; Marsh, P. The 2017 North Bay and Southern California Fires: A Case Study. Fire 2018, 1, 18. [CrossRef]

84. Rosenfeld, D.; Fromm, M.; Trentmann, J.; Luderer, G.; Andreae, M.O.; Servranckx, R. The Chisholm firestorm: Observed microstructure, precipitation and lightning activity of a pyro-cumulonimbus. Atmos. Chem. Phys. 2007, 7, 645-659. [CrossRef]

85. Fernandes, P.M.; Barros, A.M.G.; Pinto, A.; Santos, J.A. Characteristics and controls of extremely large wildfires in the western Mediterranean Basin. J. Geophys. Res. Biogeosci. 2016, 121, 2141-2157. [CrossRef]

86. Gill, A.M.; Moore, P.H.R. Fire intensities in Eucalyptus forests of southeastern Australia. In Proceedings of the International Conference on Forest Fire Research, Coimbra, Portugal, 19-22 November 1990.

87. Venäläinen, A.; Korhonen, N.; Hyvärinen, O.; Koutsias, N.; Xystrakis, F.; Urbieta, I.R.; Moreno, J.M. Temporal variations and change in forest fire danger in Europe for 1960-2012. Nat. Hazards Earth Syst. Sci. 2014, 14, 1477-1490. [CrossRef]

88. Hammill, K.; Bradstock, R.A. Spatial patterns of fire behaviour in relation to weather, terrain and vegetation. Proc. R. Soc. Qld. 2008, 115, 127-133.

89. Abatzoglou, J.T.; Kolden, C.A. Relationships between climate and macroscale area burned in the western United States. Int. J. Wildland Fire 2013, 22, 1003-1020. [CrossRef]

90. Price, O.F.; Bradstock, R.A. The efficacy of fuel treatment in mitigating property loss during wildfires: Insights from analysis of the severity of the catastrophic fires in 2009 in Victoria, Australia. J. Environ. Manag. 2012, 113, 146-157. [CrossRef] [PubMed]

91. Veraverbeke, S.; Lhermitte, S.; Verstraeten, W.W.; Goossens, R. The temporal dimension of differenced Normalized Burn Ratio (dNBR) fire/burn severity studies: The case of the large 2007 Peloponnese wildfires in Greece. Remote Sens. Environ. 2010, 114, 2548-2563. [CrossRef]

92. Birch, D.S.; Morgan, P.; Kolden, C.A.; Abatzoglou, J.T.; Dillon, G.K.; Hudak, A.T.; Smith, A.M.S. Vegetation, topography and daily weather influenced burn severity in central Idaho and western Montana forests. Ecosphere 2015, 6, art17. [CrossRef]

93. Jones, B.M.; Kolden, C.A.; Jandt, R.; Abatzoglou, J.T.; Urban, F.; Arp, C.D. Fire behavior, weather, and burn severity of the 2007 Anaktuvuk River Tundra Fire, North Slope, Alaska. Arct. Antarct. Alp. Res. 2009, 41, 309-316. [CrossRef]

94. McRae, R. Extreme Fire-A Handbook; ACT Government and Bushfire Cooperative Research Centre: East Melbourne, Australia, 2010.

95. Leonard, S.W.J.; Bennett, A.F.; Clarke, M.F. Determinants of the occurrence of unburnt forest patches: Potential biotic refuges within a large, intense wildfire in south-eastern Australia. For. Ecol. Manag. 2014, 314, 85-93. [CrossRef]

96. Cheney, N.P. The effectiveness of fuel reduction burning for fire management. In Fire and Biodiversity: The Effects and Effectiveness of Fire Management, Proceedings of the Conference, Footscray, Victoria, 8-9 October 1994; Department of the Environment, Sport and Territories, Biodiversity Unit: Canberra, Australia, 1996; pp. 9-16.

97. Bradstock, R.A.; Hammill, K.A.; Collins, L.; Price, O. Effects of weather, fuel and terrain on fire severity in topographically diverse landscapes of south-eastern Australia. Landsc. Ecol. 2010, 25, 607-619. [CrossRef]

98. Wood, S.W.; Murphy, B.P.; Bowman, D.M.J.S. Firescape ecology: How topography determines the contrasting distribution of fire and rain forest in the south-west of the Tasmanian Wilderness World Heritage Area. J. Biogeogr. 2011, 38, 1807-1820. [CrossRef]

99. Alexander, M.E.; Cruz, M.G. Interdependencies between flame length and fireline intensity in predicting crown fire initiation and crown scorch height. Int. J. Wildland Fire 2012, 21, 95-113. [CrossRef]

100. Kirkpatrick, J.B.; Núñez, M. Vegetation-Radiation Relationships in Mountainous Terrain: Eucalypt-Dominated Vegetation in the Risdon Hills, Tasmania. J. Biogeogr. 1980, 7, 197-208. [CrossRef]

101. Kumar, L.; Clarke, P.; Muñoz, C.; Knox, K. Mapping of fire severity and comparison of severity indices across vegetation types in Gibraltar Range National Park, Australia. Int. Arch. Photogram. Remote Sens. Spat. Inf. Sci. 2008, 37, 1477-1482. 
102. Harris, S.; Veraverbeke, S.; Hook, S. Evaluating spectral indices for assessing fire severity in chaparral ecosystems (Southern California) using MODIS/ASTER (MASTER) airborne simulator data. Remote Sens. 2011, 3, 2403-2419. [CrossRef]

103. Brewer, C.K.; Winne, J.C.; Redmond, R.L.; Opitz, D.W.; Mangrich, M.V. Classifying and mapping wildfire severity. Photogramm. Eng. Remote Sens. 2005, 71, 1311-1320. [CrossRef] 